\title{
Police Body-Worn Cameras
}

by Alexandra Mateescu, Alex Rosenblat and danah boyd

Published by Data \& Society Research Institute, with support from Robinson \& Yu ${ }^{1}$

Working Paper ${ }^{2}$

February 2015

\section{Introduction}

In the wake of the police shooting of Michael Brown in August 2014, as well as the subsequent protests in Ferguson, Missouri and around the country, there has been a call to mandate the use of body-worn cameras to promote accountability and transparency in policecivilian interactions. Body-worn cameras have received positive appraisal from the NAACP Legal Defense \& Education Fund, ${ }^{3}$ and the American Civil Liberties Union (ACLU). The latter has stated that their widespread use "[has] the potential to be a win-win, helping protect the public against police misconduct, and at the same time helping protect police against false accusations of abuse." "In 2013, the Police Executive Research Forum (PERF) sent surveys to 500 of the 12,501 police departments in the U.S, ${ }^{5}$ and of the 254 who completed the survey only 63 of the departments reported using body-worn cameras. ${ }^{6}$ However, law enforcement agencies throughout the country are now rapidly adopting the cameras. In December 2014, President Obama proposed the Body-Worn Camera Partnership Program, which aims to invest \$75 million through a 50\% investment matching arrangement with states and localities to cover video storage and equipment expenses, with the goal of underwriting the costs of 50,000 body-worn cameras. ${ }^{7}$ The program is part of a broader three-year, \$263 million initiative to strengthen community policing, ${ }^{8}$ and the funding plan is part of President Obama's proposed FY2016 budget. ${ }^{9}$

\footnotetext{
${ }^{1}$ We are very grateful for the strong contributions and insights made by Jenna Leventoff and David Robinson from Robinson \& Yu in the research and production of this primer.

${ }^{2}$ This work is licensed under a Creative Commons Attribution 4.0 International License

${ }^{3}$ Letter from Sherrilyn Ifill, President, NAACP Legal Defense \& Education Fund, to Eric Holder, August 14, 2014, http://www.naacpldf.org/files/case issue/8-14-

2014\%20Letter\%20to\%20AG\%20Holder\%20re\%20use $\% 20$ of $\% 20$ excessive $\% 20$ force $\% 20$ by $\% 20$ police.pdf

${ }^{4}$ Jay Stanley, "Police Body-Mounted Cameras: With Right Policies in Place, a Win For All," American Civil Liberties Union, October 9, 2014, accessed January 16, 2015, https://www.aclu.org/technology-and-liberty/police-body-mounted-cameras-right-policies-place-winall.

${ }^{5}$ Number of U.S. police departments as of 2008. U.S. Department of Justice, Office of Justice Programs, Bureau of Justice Statistics, Census of State and Local Law Enforcement Agencies, 2008, written by Brian A. Reaves, NCJ 233982, p. 1, accessed January 16, 2015, http://www.bjs.gov/content/pub/pdf/csllea08.pdf

${ }^{6}$ PERF sent out a survey to 500 agencies, of which 254 responded. See Lindsay Miller, Jessica Toliver and Police Executive Research Forum (PERF), Implementing a Body-Worn Camera Program: Recommendations and Lessons Learned (Washington, DC: Office of Community Oriented Policing Services, 2014), p. 2.

${ }^{7}$ David Hudson, "Building Trust Between Communities and Local Police," Whitehouse.gov, December 1, 2014, accessed January 16, 2015, http://www.whitehouse.gov/blog/2014/12/01/building-trust-between-communities-and-local-police.

${ }^{8}$ David Hudson, "Building Trust Between Communities and Local Police."
} 
Little is known about the potential long-term impact of body-worn cameras. There has been no large-scale, systematic empirical research on their usage or implementation, and the evidence available today is based on small, local studies with limited generalizability. Many uncertainties about best practices remain, including when the cameras should record, what should be stored and retained, and what policies should determine the release of footage to the public.

Both law enforcement and civil rights advocates are excited by the potential of body-worn cameras to improve accountability and transparency in policing, and more pointedly, to reduce the deaths of black male civilians in encounters with police. However, there is no conclusive evidence to suggest that a wide roll-out of police body-worn cameras across many variable departments and jurisdictions will bring about the accountability, transparency, and changes to community policing that are being touted as the crucial tenets of their potential impact, especially given that many fatal or brutal encounters between police and civilians have, in fact, been captured on camera. Indeed, during the trial of the LAPD officers who were captured on camera beating Rodney King, their defense lawyers successfully argued that the camera failed to capture the allegedly aggressive behavior of King that precipitated their use of force to subdue him. ${ }^{10}$ The use of camera footage, coupled with narratives about the aggressive or otherwise provocative behavior of the camera's subject(s), can be used to legitimize the use of force against subjects in ways that continue to justify the types of policing practices that culminated in Michael Brown's death. ${ }^{11}$ Moreover, it is important to recognize that police body-worn cameras alone will not resolve deep-seated issues that lead to the hyper-surveillance policing of black communities, and could potentially exacerbate them.

As pilot and permanent body-worn camera programs are implemented, it is important to ask questions about how they can be best used to achieve their touted goals. Will these devices make law enforcement more accountable to the public or will they usher in a new era of surveillance, deception, and abuse? Who will have access to the footage and under what circumstances? How will judges, juries, and the public interpret what is recorded? How will the implementation of these programs be assessed for their efficacy in achieving accountability goals? What are the best policies to have in place to support those goals?

Although many police departments currently using body-worn cameras have formal policies covering some key issues, such as when to record and how long to retain recordings, those policies will likely need to evolve as departments develop better understandings of how bodyworn cameras affect policing practices on the ground. Prosecutors and defense lawyers will need to better understand how footage is used to negotiate pretrial settlements, and courts will also have to develop new practices and policies for the courtroom use of such footage. Policies that effectively address body-worn cameras will also necessarily need to consider a number of related technologies which may be integrated with the cameras, such as facial recognition and other biometrics, data transfer methods, as well as storage and analysis tools.

\footnotetext{
${ }^{9}$ Congressman Emanuel Cleaver II, "Congressman Cleaver and Congressman Green Secure Inclusion of Body Camera Funding in President's Budget," Congressman Emanuel Cleaver II, Press Release, February 2, 2015, accessed February 08, 2015, http://cleaver.house.gov/media-center/press-releases/congressman-cleaver-and-congressman-green-secure-inclusion-of-body.

${ }^{10}$ Earl Ofari Hutchinson, “Would a Body Camera Have Saved Michael Brown?” Huffington Post, September 25, 2014, accessed January

14, 2015, http://www.huffingtonpost.com/earl-ofari-hutchinson/would-a-body-camera-have- b 5879356.html.

${ }^{11}$ Ben Brucato, “The Reason Mike Brown Can't Get Justice Has Nothing To Do With Cameras," Ben Brucato, December 4, 2014, accessed February 18, 2014, http://www.benbrucato.com/?p=642.
} 
This primer offers an overview of what is currently known about body-worn cameras, and highlights the unanswered questions about how body-worn camera programs may impact civil rights and civil liberties.

\section{Table of Contents}

1. The Evolution of Video Surveillance

2. What are Body-Worn Cameras?

a. Location of the Camera Mount

b. Recording Capabilities

c. Evidentiary Safeguards

d. Tracking Features

e. Video Management

3. Summary of Pilot Studies on Police Body-Worn Cameras

4. Key Policy Questions

5. When Will Cameras Be Running, and How Will Subjects Know?
a. Activating and Turning Off Cameras
b. Officer Discretion
c. Exceptions
d. Department Policies: When Officers Should Record
e. Public Notice and Consent to Be Recorded
f. Recording Capabilities
g. Evidentiary Safeguards
h. Tracking Features
i. Video Management

6. How Long Will Law Enforcement Agencies Retain Footage, and Who Can See It?
a. Retention Times and Access to Footage
b. Footage as Evidence
c. Categorized and Uncategorized Video
d. Lengthy Retention Times and Civil Rights
e. Rules for Viewing By Police
f. Rules for Public Access

7. How Is Footage Secured? Cloud Storage of Video Data

8. When Can Biometrics be Collected or Used?

9. Cameras Cannot Tell the Full Story
a. Limits to the Camera's Point of View
b. Perspective and Bias in Video Interpretation
c. Case Study
d. Interpreting Video Evidence in Court
e. Footage as a Performance Metric
f. Data on Police-Civilian Interactions

10. Conclusion and Future Work

11. Appendix I

12. Works Cited 


\section{The Evolution of Video Surveillance}

Stationary video surveillance, such as closed-circuit television (CCTV), has become a ubiquitous tool of policing. ${ }^{12}$ CCTV rose to prominence in the 70's and 80's as a means to monitor public spaces including roads, public transportation hubs, parking lots, retail spaces, malls, and other privately owned public spaces. ${ }^{13}$ Stationary surveillance cameras in public spaces were initially employed for crime-control and, subsequently, for anti-terrorism efforts. ${ }^{14}$ Their use is rooted in deterrence theory, which posits that the awareness of being scrutinized will deter potential criminals for fear of apprehension. ${ }^{15}$ As a form of "public order policing," surveillance could encourage civilians and officers to behave in a less confrontational manner towards each other. ${ }^{17}$ However, the deterrent potential of cameras may be overestimated. While there is no clear-cut evidence of their efficacy in reducing crime, past studies have shown that public CCTV surveillance may deter crimes or they may merely displace them to other areas ${ }^{18}$; they may have a negligible effect on violent crime $^{19}$; they may even increase other types of crime, such as petty theft, because victims gain a false sense of security over their belongings from the presence of cameras ${ }^{20}$; and when their impact is significant, it may be limited to certain areas, like car parks. ${ }^{21}$

Mobile forms of police video surveillance became more common with the spread of dashboard-mounted cameras in police cruisers, more commonly referred to as "dashcams." These were initially implemented as a means of supporting convictions in cases of traffic stops for Driving-Under-Influence or Driving-While-Intoxicated, as well as in drug arrests, and to document consent in vehicular searches. ${ }^{22}$ As of 2007 , dashcams were being used by $61 \%$ of police departments, ${ }^{23}$ but their utility is limited to interactions within the camera's view that take place around vehicles, unlike mobile body-worn cameras, which accompany police throughout the course of their duties.

\footnotetext{
${ }^{12}$ Michael D. White, Police Officer Body-Worn Cameras: Assessing the Evidence (Washington, DC: Office of Community Oriented Policing Services, 2014), p. 12. https://ojpdiagnosticcenter.org/sites/default/files/spotlight/download/Police\%20Officer\%20BodyWorn\%20Cameras.pdf.

${ }^{13}$ Randy Lippert and David Murakami Wood, "New Urban Surveillance: Technology, Mobility, and Diversity in 21st Century Cities." Surveillance \& Society 9, no. 3 (2012): 257-262.

${ }^{14}$ David Lyon, Kevin D. Haggerty, and Kirstie Ball, Routledge Handbook of Surveillance Studies (Abingdon, Oxon; New York:

Routledge, 2012), p. 252.

${ }^{15}$ Ibid, p. 256.

${ }^{16}$ White, Assessing the Evidence, p. 41.

${ }^{17}$ Tony Farrar, "Self-Awareness to Being Watched and Socially-Desirable Behavior: A Field Experiment on the Effect of Body-Worn Cameras on Police Use-of-Force," Police Foundation, accessed January 12, 2015, http://www.policefoundation.org/content/body-worncamera.

${ }^{18}$ Brandon C. Welsh and David P. Farrington, "Public Area CCTV and Crime Prevention: An Updated Systematic Review and MetaAnalysis," Justice Quarterly 26, no. 4 (December 1, 2009), p. 728.

${ }^{19}$ Ibid, p. 734.

${ }^{20}$ Ibid, p. 717.

${ }^{21}$ Ibid, p. 716.

${ }^{22}$ International Association of Chiefs of Police, The Impact of Video Evidence on Modern Policing: Research and Best Practices from the IACP Study on in-Car Cameras (Alexandria, Va.: International Association of Chiefs of Police, 2005), http://www.cops.usdoj.gov/Publications/video_evidence.pdf.

${ }_{23}$ Bureau of Justice Statistics, "Local Police Departments, 2007," U.S. Department of Justice, by Brian A. Reaves, December 2010 , p. 21, accessed January 10, 2015, http://www.bjs.gov/content/pub/pdf/lpd07.pdf.
} 


\section{What are Body-Worn Cameras?}

A 2012 report by the Office of Justice Programs National Institute of Justice, within the U.S. Department of Justice, defines body-worn cameras as "mobile audio and video capture devices that allow officers to record what they see and hear. Devices can be attached to various body areas, including the head... or to the body by pocket... [and] they have the capability to record officer interactions that previously could only be captured by in-car or interrogation room camera systems." 24 Other types of mobile video capture in use by police departments include cameras that mount onto tasers (electroshock weapons), ${ }^{25}$ dashboard-mounted cameras, and gunmounted cameras such as the PistolCam, which present some of the same policy and use concerns as body-worn cameras, although they are not commonly used at present.

There are many makes and models of body-worn cameras, each with different features and capabilities. In March 2014, the National Institute of Justice published a market report that examined the features of 18 different models of body-worn cameras. ${ }^{26}$ The most salient of these features from a civil rights perspective are:

Location of the Camera Mount: Where a camera is mounted determines what the camera sees. The most common mount is the chest, ${ }^{27}$ but chest mounts may not capture the full scene. Lapel mounts (slightly higher up on the uniform) give a better view, but may be more likely to be knocked off during altercations. ${ }^{28}$ Head mounts (usually located on sunglasses) record most closely "exactly what the officer is seeing," 29 unlike lapel or chest mounts, which don't account for what the officer sees when they swivel their head away from the direction their body is facing, but officers cannot always wear sunglasses, and some find head mounts uncomfortable. ${ }^{30}$

Recordling Capabilities: Some models of body-worn cameras have continuous recording capabilities (sometimes called a "pre-record buffer") ${ }^{31}$ that allow the cameras to keep the footage from just before a triggering event. ${ }^{32}$ For example, the AXON Body by TASER constantly records footage, and automatically keeps the 30 seconds of video before the officer presses the record button, as well as what happens after. ${ }^{33}$ Those additional 30 seconds of footage are meant to ensure that the videos include the context leading up to an event, and may be helpful if an officer does not press record in the immediate heat of an altercation. Although

\footnotetext{
${ }^{24}$ National Institute of Justice, “A Primer on Body Worn Cameras for Law Enforcement,” JustNet, September 2012, p. 5, accessed January 10, 2015, https://www.justnet.org/pdf/00-Body-Worn-Cameras-508.pdf.

25 "Taser Cam HD," TASER International, accessed January 12, 2015, http://www.taser.com/products/on-officer-video/taser-cam-hd.

${ }^{26}$ See U.S. Department of Justice Office of Justice Programs, National Institute of Justice, "Body-Worn Cameras for Criminal Justice:

Market Survey Version 1.0" (March 2014), https://www.justnet.org/pdf/Body-Worn-Camera-Market-Survey-508.pdf.

${ }^{27}$ PERF Report, p. 39.

${ }^{28}$ Peter Hermann, "D.C. Poised to Test Body Cameras for Police Officers," Washington Post, September 6, 2014, accessed January 10 , 2015, http://www.washingtonpost.com/local/crime/dc-poised-to-test-body-cameras-for-police-officers/2014/09/06/358ebc52-3459-11e4a723-fa3895a25d02_story.html.

${ }^{29}$ National Institute of Justice, “A Primer on Body Worn Cameras for Law Enforcement,” p. 6.

${ }^{30}$ PERF Report, p. 39.

${ }^{31}$ Of the 18 cameras examined in the Market Survey, 9 models had pre-event record capabilities. See U.S. Department of Justice Office of Justice Programs, National Institute of Justice, "Body-Worn Cameras for Criminal Justice: Market Survey Version 1.0” (March 2014).

32 "Facts About Body Worn Cameras (BWC)," City of Fort Collins, Colorado, accessed February 9, 2015, http://www.fcgov.com/police/pdf/facts-body-worn-camera.pdf.

33 "Body Cameras Want to Change Law Enforcement," American Photo, accessed January 10, 2015, http://www.americanphotomag.com/node/3130.
} 
many cameras can record continuously, there are significant concerns about privacy, and some police departments have determined that the volume of video associated with continuous recording would be too costly to store and maintain. ${ }^{34}$ The marginal cost of storing extra hours of video, however, is likely to decline in tandem with the plummeting cost of all kinds of digital storage. $^{35}$

Evidentiary Safeguards: In order for body-worn camera video footage to be admissible in court, the person seeking to submit it "must provide evidence of its identity and integrity, usually by showing a chain of custody tracking the item from its acquisition to its presentation at trial." 36 Many body-worn camera models offer various safeguards to ensure that the data is not manipulated. ${ }^{37}$ The AXON Body by TASER International forbids users from deleting a video on the camera and marks the video with a security hash, ${ }^{38}$ which verifies that the video hasn't been tampered with. ${ }^{39}$ The FirstVu HD from Digital Alley offers optional software that logs each use of the video and generates a chain of custody report. ${ }^{40}$ Notably, the evidentiary standards used in court are higher than those that can be used at the plea bargain stage. Video footage without the evidentiary safeguards required to make it admissible in court could still be used persuasively in pretrial situations.

Tracking Features: Time/Date stamps and GPS functions can also help to protect the authenticity and integrity of videos. ${ }^{41}$ Every body-worn camera examined in the market report has a time/date stamp embedded in the recorded video. ${ }^{42}$ However, few models have GPS capabilities that can imprint the recording location onto the video (a feature sometimes called "geotagging"). ${ }^{43}$ Incidents can spread out over multiple locations, ${ }^{44}$ and the lack of precise location metadata can decrease the evidentiary value of these recordings. Theoretically, for assessment purposes, the aggregate location data can also be used to map where use of force or other incidents take place, in order to pinpoint sources of problematic police-public

\footnotetext{
${ }^{34}$ PERF Report, p. 32.

${ }^{35}$ Amit Kumar Dutta et. al, "How Much Does Storage Really Cost? - Towards a Full Cost Accounting Model for Data Storage," University of Alabama at Birmingham, accessed February 6, 2015, http://secret.cis.uab.edu/media/dutta-2013-full-cost-accountinggecon.pdf.

${ }^{36}$ David Paul Horowitz, "Take My Evidence ... Please!," N.Y. St. B.J., October 2007, pp. 22, 24.

${ }^{37}$ Of the 18 cameras examined in the Market Survey, 16 models had "video safeguards." See U.S. Department of Justice Office of Justice Programs, National Institute of Justice, "Body-Worn Cameras for Criminal Justice: Market Survey Version 1.0” (March 2014). 
interactions ${ }^{45}$ The same predictive policing tactics used to identify hotspots of criminal activity could be similarly used to predict hotspots of violent police-civilian encounters, and to identify the factors that contribute to these, in an effort to promote transparency and accountability in the geographies of community-police relations that could most benefit from it. ${ }^{46}$

Video Management: Video software allows users to manage the body-worn camera recordings ${ }^{47}$ A popular cloud-based video management tool, Evidence.com (owned by TASER International) markets itself as a "digital evidence management system that allows the agency to securely store and track access to any type of digital evidence. $"$ "

\section{Summary of Pilot Studies on Police Body-Worn Cameras}

Different university-based researchers have led pilot studies on the implementation of bodyworn cameras in some of the police departments that have adopted them, namely in Rialto, CA, Mesa, AZ, Phoenix, AZ, Seattle, WA, Albuquerque, NM, Orlando, FL, Oakland, CA, and New Orleans, LA.

As police, public, and governmental support for body-worn cameras grows, it is important to note that body-worn cameras are not being adopted and implemented in a randomized, scientific fashion across the country. This poses a challenge to assessing their impact. While some concerns about body-worn camera usage are consistent across diverse departments, the conclusions that can be drawn from the current use of body-worn cameras are largely tentative. For instance, the conclusions derived from a study within a small community where everyone knows each other, or a study conducted within a spread-out community where police are more often in vehicles, will not be equally applicable to a city with a highly dense population, where police are more often on foot and will routinely capture images of thousands of people. That said, departments that are evaluating these technologies should be commended and those considering deploying body-worn cameras in their communities should develop a protocol to assess the roll-out in their own jurisdiction. The more information we have about how these technologies function in different communities, the better informed other jurisdictions can be about how to successfully implement body-worn cameras. Specific descriptions of each pilot study are attached to this primer as Appendix I.

\section{Major Takeaways from the Pilot Studies}

- The use of body-worn cameras is reported to have a civilizing effect on police-civilian interactions, ${ }^{49}$ and to cause a reduction in use of force incidents. ${ }^{50}$

\footnotetext{
${ }^{45}$ Andrew Guthrie Ferguson, "Creating Smarter Police Body-Worn Cameras," Huffington Post, December 8, 2014, accessed January 12, 2015, http://www.huffingtonpost.com/andrew-guthrie-ferguson/creating-smarter-police-b b 6288482.html.

${ }^{46}$ Ibid.

${ }^{47}$ U.S. Department of Justice Office of Justice Programs, National Institute of Justice, "Body-Worn Cameras for Criminal Justice: Market Survey Version 1.0" (March 2014), p. 7.

48 “About AXON Cameras from TASER International," TASER International, accessed December 22, 2014, http://www.taser.com/images/press-room/TASERAXON-EVIDENCEcomPressKit020314.pdf.

${ }^{49}$ PERF Report, p. 40.

${ }^{50}$ Ibid, p. 8.
} 
- Researchers caution that the cognitive awareness of being recorded is partly responsible for the reduction in use of force incidents, in contrast to incidents that are filmed by bystanders, where police are not necessarily aware of being recorded, nor are the civilians they are engaging with; the act of announcing that one is being recorded can have a significant deterrent effect. ${ }^{51}$

- This benefit underscores concerns that police should directly inform subjects, or that a light on their cameras should directly communicate, that the camera is actively recording, even if police are not legally obliged to get the consent of those being recorded or to notify them.

- Footage collected by police departments presents a public-records issue. Seattle PD in particular has been bombarded with anonymous public-records requests for footage, and is grappling with how to satisfy the requests in a way that is less costly and time consuming; all footage has to be reviewed, and private details redacted, before it can be released to the public.

- In some departments, like Albuquerque, there have been notable inconsistencies in implementation, where the cameras are not always turned on, and thus do not record incidents involving police-civilian disputes. ${ }^{52}$

- The storage and data management costs have been cited by many departments, like Orlando, as a major obstacle to implementation. ${ }^{53}$

- Generally, the departments assessed through pilot studies find that the cameras are a worthwhile investment, in particular because they can often reduce viable complaints made against officers, who can use the footage as evidence of their good conduct. ${ }^{54}$

\section{Key Policy Questions}

Departments considering implementing a body-worn camera program should look to the legal concerns at stake, the policies and pilot studies of other police departments, and the recommendations of the police and civil liberties groups who have addressed what a model policy looks like.

Police departments and communities looking to implement body-worn camera programs face many difficult questions that will require them to balance competing interests. These questions include: (1) when will the cameras be running? (2) how will people know that they are on camera and can they ask that it be turned off? (3) who can see the footage and how long will it be retained? and (4) when can biometrics be collected or used?

\footnotetext{
${ }^{51}$ Fred Lewsey, "First Scientific Report Shows Police Body-Worn-Cameras Can Prevent Unacceptable Use-of-Force," University of Cambridge, December 23, 2014, accessed February 08, 2015, http://www.cam.ac.uk/research/news/first-scientific-report-shows-policebody-worn-cameras-can-prevent-unacceptable-use-of-force.

${ }_{52}$ U.S. Department of Justice, Civil Rights Division, Letter to Richard J. Berry, Mayor of City of Albuquerque (April 10, 2014), accessed January 14, 2015, http://www.justice.gov/crt/about/spl/documents/apd_findings_4-10-14.pdf.

${ }^{53}$ Mark Schlueb, "Orlando Police Warming up to Body Cameras," OrlandoSentinel.com, December 12, 2014, accessed January 12, 2015, http://www.orlandosentinel.com/news/breaking-news/os-opd-police-body-cams-20141212-story.html.

${ }^{54}$ Ian Lovett, "In California, a Champion for Police Cameras," New York Times, August 21, 2013, accessed January 28, 2015, http://www.nytimes.com/2013/08/22/us/in-california-a-champion-for-police-cameras.html?pagewanted=all\&_r=0.
} 
In exploring the uses and practices of body-worn cameras, this primer will address model policies created by the Police Executive Research Forum (PERF), the International Association of Chiefs of Police (IACP), and the American Civil Liberties Union (ACLU), as well as policy recommendations from the Leadership Conference on Civil and Human Rights (LCCHR), the Center for Democracy and Technology (CDT), the New York Civil Liberties Union (NYCLU) and the Constitution Project.

This document will also examine the limited number of publicly available in-use department policies. Among the respondents to PERF's survey, nearly $1 / 3$ of agencies using body-worn cameras reported that they do not have any written policies. ${ }^{55}$ Among the departments that do have written policies, few have made those policies public. At the time of this report's drafting, we identified only eleven such policies online. Those policies are the only ones used to form the basis of this report, but departments looking to create body-worn camera policies should consider that the roll-out of this technology is new, and it will take further work to design policies that expressly support the goals of transparency and accountability, and which ultimately improve community policing.

\section{When Will Cameras Be Running, and How Will Subjects Know?}

\section{Activating and Turning Off Cameras}

The use of body-worn cameras by police officers when they are interacting with or passing by civilians in the course of their duties raises a number of privacy concerns. ${ }^{56}$ For example, embarrassing dashcam video footage of the arrests or traffic stops of naked women, athletes, and celebrities are sometimes disseminated online, ${ }^{57}$ and the same privacy concerns exist about the potential for body-camera footage to be consumed as public entertainment. Since body-worn cameras accompany police officers in the course of their duties, they can represent a greater intrusion to privacy than dashcams, since officers can enter people's homes or places where there is generally a greater expectation and sometimes a legal protection of privacy.

Current state and federal laws leave many police agencies with broad discretion to set policies for when and where subjects will be recorded by body-worn cameras. In ten states, California, Connecticut, Florida, Illinois, Maryland, Massachusetts, Montana, New Hampshire, Pennsylvania, and Washington, wiretap laws require "two-party consent," 58 police will have to obtain consent to record from the person(s) they are recording, ${ }^{59}$ unless specific statutory exemptions apply to law enforcement activities. For example, in February 2014, Pennsylvania enacted Senate Bill 57, which waives the consent requirement for police officers. ${ }^{60}$ At the federal

\footnotetext{
${ }^{55}$ PERF Report, p. 2.

${ }^{56}$ Matt Pearce, "Growing Use of Police Body Cameras Raises Privacy Concerns," Los Angeles Times, accessed February 6, 2015, http://www.latimes.com/nation/la-na-body-cameras-20140927-story.html\#page=1. 
level, Fourth Amendment protections generally limit searches of private places such as a person's home. ${ }^{61}$ Moreover, the recent case United States $v$. Jones case suggests that pervasive surveillance of a person's activities while in public may ultimately raise Fourth Amendment concerns if the surveillance is intensive and prolonged. ${ }^{62}$

\section{Officer Discretion}

Aside from the limitations imposed by state-level wiretap laws and potential Fourth Amendment constraints, department policy will guide officers as to when they must record. The PERF and IACP model policies agree that officers should have some level of discretion in deciding what and when to record, in particular regarding vulnerable persons, like the victims of sexual assault. Undocumented migrants or witnesses who fear reprisal from their testimony may also be hesitant to confide their accounts to officers who are obliged to record them. Both of the model policies suggest that officers should generally record interactions with subjects when such interactions are related to the officer's duties. The IACP model policy requires officers record all contact unless the individual has a reasonable expectation of privacy, in which case the officer must seek consent to record. ${ }^{63}$ The PERF report recommends that officers activate their cameras when they respond to a specific call, during law enforcement-related encounters, and particularly during adversarial encounters, unless it is ill-advised to do so for reasons of safety or practicality. ${ }^{64}$ Instead of defining "law enforcement-related encounters and activities," the PERF report defers this crucial question, advising departments to "clearly define" the term for themselves, and to consider providing examples in their policy. ${ }^{65}$ The Leadership Conference recommends that officers should record all interactions with the public while on duty, except when a specific, well-defined exception applies. ${ }^{66}$

\section{Exceptions}

It is common for policies to have exceptions to their general recording rules that require or allow officers to stop recording in some subset of the cases where recording is generally expected (such exceptions often follow the lead of the PERF and IACP model policies). Some policies state that officers may refrain from recording when doing so would be unsafe or impractical. ${ }^{67}$ Other exceptions to the rule may forbid officers from recording nudity or private places. For example, Grand Forks, North Dakota requires officers to deactivate their cameras

\footnotetext{
61 'It is a 'basic principle of Fourth Amendment law' that searches and seizures inside a home without a warrant are presumptively unreasonable." Payton v. New York, 445 U.S. 573, 586 (1980).

${ }^{62}$ See United States v. Jones, 132 S. Ct. 945, 947 (2012). See also Marc Jonathan Blitz, The Fourth Amendment Future of Public Surveillance: Remote Recording and Other Searches in Public Space, 63 Am. U. L. Rev. 21, 26 (2013) ("These five justices suggested that an important constitutional line is crossed--and the constraints of the Fourth Amendment are triggered--when public surveillance becomes too intense or prolonged"); Benjamin J. Priester, Five Answers and Three Questions After United States v. Jones (2012), the Fourth Amendment "Gps Case", 65 Okla. L. Rev. 491, 492 (2013) (examining the meaning of Jones).

${ }^{63}$ IACP, Body-Worn Cameras Model Policy, p. 1.

${ }^{64}$ PERF Report, p. 40.

${ }^{65}$ Ibid, p. 40.

${ }^{66}$ Letter from Wade Henderson, President and CEO, Leadership Conference on Civil and Human Rights (LCCHR) and Nancy Zirkin, Executive Vice President, LCCHR to the President's Task Force on 21st Century Policing, January 30, 2015, p. 2, http://www.civilrights.org/advocacy/letters/2015/21st-century-policing.html.

${ }^{67}$ See Rialto Police Department, "Body Worn Video Systems," accessed January 14, 2015, p. 1, http://www.lris.com/wpcontent/uploads/2014/09/Rialto-Policy-on-Body-Cams.pdf; Las Vegas Metropolitan Police Department, "GO-009-14 Supp No 2," August 28, 2014, accessed December 30, 2014, https://static.spokanecity.org/documents/police/accountability/bodycamera/las-vegaspolicy.pdf.
} 
when "sensitive human areas are exposed." 68 Likewise, San Diego's policy forbids recording when "persons have a reasonable expectation of privacy." ${ }^{\text {"69 }}$ Burlington, Vermont's policy grants officers the discretion to "try to avoid" recording nude persons. ${ }^{70}$ Some policies also give officers discretion to avoid recording victims or witnesses. Grand Forks, North Dakota allows officers to deactivate body-worn cameras to prevent recording "victims of sex offenses."71 Marianna, Florida gives officers discretion not to record when "persons are unwilling to share information about a crime if they are being recorded." 72 Las Vegas, Nevada bars recording "a formal statement from a victim or a witness." "73 Of the eleven polices examined for this report, eight say that officers should generally stop recording an event when that event is complete. ${ }^{74}$ The IACP model policy also states that officers should document why they failed to record or stopped recording an event that was suitable for recording under the department's policy. ${ }^{75}$

In the future, automatic recording triggers may make this issue less contentious. An ACLU statement observes that some dashboard-mounted cameras are equipped with automated triggers that activate filming when a car's siren or lights are activated. A similar system could be developed for body-worn cameras to detect triggers such as raised voices or certain types of movement. ${ }^{76}$ In January 2015, for example, the Los Angeles Police Department announced plans to equip officers with body-worn cameras that automatically turn on when the officer's taser is activated. ${ }^{77}$ Accordingly, improved technology may create more standardized policies regarding when to record.

\section{Department Policies: When Officers Should Record}

The eleven department policies that are publicly available come from the respective police departments of New Orleans, Louisiana; Burlington, Vermont; Las Vegas, Nevada; Minneapolis, Minnesota; San Diego, California; Marianna Florida; Peoria, Arizona; Greenville, South

\footnotetext{
${ }^{68}$ Grand Forks Police Department, "Directive: Body-Worn Camera Recording Equipment," Grand Forks Herald, (revised November 26, 2014) accessed January 14, 2015, p. 2, http://www.grandforksherald.com/sites/default/files/4113.pdf.

${ }^{69}$ San Diego Police Department, "Axon Body Worn Cameras," p. 6.

${ }^{70}$ Burlington Police Department, "Department Directive DD14 DigitalImaging, Digital Audio \& Video, and Body Worn Camera Systems," City of Burlington, p. 4, accessed January 14, 2015, http://www.burlingtonvt.gov/sites/default/files/police/files/DD14\%20\%20Digital\%20Imaging, \%20Digital\%20Audio\%20\%26\%20Video, $\% 20$ and $\% 20$ Body $\% 20$ Worn $\% 20$ Camera $\% 20$ Systems.pdf.

${ }^{71}$ Grand Forks Police Department, "Directive: Body-Worn Camera Recording Equipment," p. 2.

72 Marianna Police Department, "Mobile Video/Audio Recording Equipment," City of Marianna, p. 5, accessed December 30, 2014, http://www.cityofmarianna.com/AgendaCenter/ViewFile/Item/398? fileID=8394.

${ }^{73}$ Las Vegas Metropolitan Police Department, “GO-009-14 Supp No 2,” August 28, 2014, p. 3, accessed December 30, 2014, https://static.spokanecity.org/documents/police/accountability/bodycamera/las-vegas-policy.pdf.

${ }^{74}$ Recording shall not cease "until an investigative or enforcement contact or incident has concluded," or with "supervisory approval." See New Orleans, p. 4; "Once the BWC is activated, officers will continue to record until the conclusion of their involvement in an event." See Davidson, NC, p. 2; "until the conclusion of an incident/encounter, the officer has left the scene or a supervisor has authorized (on camera) that a recording may cease."; "The [body-worn camera] equipment should remain activated until the event is completed," See Grand Forks, North Dakota, p. 1; "The [mobile video recorder] is not deactivated until the enforcement action is completed," See Greenville, South Carolina, p. 2; "Once the BWC is activated, recording will continue until the event has concluded," See Las Vegas, p. 3; "Recording can only be stopped ... after the incident has concluded." See Marianna, Florida, p. 3.; "Once activated, BWCs shall remain on through the duration of an incident," See Burlington, Vermont, p. 4. Minneapolis, Minnesota specifies that an officer may stop recording if doing so won't result in the loss of evidence. Minneapolis, Minnesota, p. 4.

${ }^{75}$ IACP Report, p. 1; Implementing Body-Worn Cameras, p. 39; "If an officer interrupts or deactivates a BWC recording once it has been initiated, the officer shall document why the recording was interrupted or terminated." See Burlington, VT, p. 2.

76 "Police Body-Mounted Cameras: With Right Policies in Place, a Win For All," American Civil Liberties Union, October 9, 2014, accessed January 16, 2015, https://www.aclu.org/technology-and-liberty/police-body-mounted-cameras-right-policies-place-win-all. ${ }^{77}$ Michael Fleeman, “L.A. Police to Get Tasers That Activate Body Cameras When Used,” Reuters, January 6, 2015, accessed January 16, 2015, http://www.reuters.com/article/2015/01/06/us-usa-california-tasers-idUSKBN0KF26B20150106.
} 
Carolina; Rialto, California; Grand Forks, North Dakota; and Davidson, North Carolina. The policies vary significantly regarding when officers should have their cameras rolling, but they generally fall within or near the range provided by the IACP and PERF recommendations. Several policies outline specific instances when officers should record, against a baseline presumption that outside of such circumstances, the camera will not be recording. ${ }^{78}$ For example, Las Vegas, Nevada's policy outlines 12 particular situations when officers should record, including: (1) stops; (2) searches; (3) calls for service; and (4) adversarial contacts. ${ }^{79}$ Rialto, California's policy similarly lists particular scenarios when officers should record, but also advises officers to activate the cameras in addition to those scenarios if they think it would be appropriate or valuable to do so. ${ }^{80}$ Along those lines, several other departments, like Peoria, Arizona ${ }^{81}$ and Marianna, Florida, ${ }^{82}$ have intentionally broad policies regarding when officers should or must record.

\section{Failure to Record and Workplace Surveillance}

The New York Civil Liberties Union asserts that officers should face consequences for failing to record. They recommend that a presumption against the officer should exist for failure to record, which an officer can rebut with proof of a mechanical malfunction. ${ }^{83}$ This presumption could ensure that the cameras do record problematic encounters, rather than being turned off in instances where the officer does not want their actions recorded. This recommendation comes in response to many well-publicized incidents where officers have turned off dashcams or bodyworn cameras during arrest, or where officers advise each other to turn off the camera during a contested or violent scene with a civilian. ${ }^{84}$

However, departments that fail to elicit support from officers for the adoption and use of body-worn cameras could potentially face an uptick in mechanical failures, or instances where the cameras' view is obstructed in some way, as a form of resistance to unwelcome workplace surveillance. When dashcams were implemented, one of the problems that departments

\footnotetext{
${ }^{78}$ See "MPD Body Camera SOP," Minneapolis Police Department, November 5, 2014, p. 2, accessed January 14, 2015, http:/www.ci.minneapolis.mn.us/www/groups/public/@mpd/documents/webcontent/wcms1p-133495.pdf; "Mobile Video/Audio Recording Equipment (MVR)," Greenville South Carolina Police Department, October 22, 2012, accessed January 15, 2015, http://thedocumentnow.com/docnow 546891b3c6fe427ccf3b95a2, pp. 2-3; "Department Directive DD14 DigitalImaging, Digital Audio \& Video, and Body Worn Camera Systems,” Burlington Police Department, pp. 3-4, accessed January 14, 2015, http://www.burlingtonvt.gov/sites/default/files/police/files/DD14\%20-

\%20Digital\%20Imaging, \%20Digital\%20Audio $\% 20 \% 26 \% 20$ Video, $\% 20$ and $\% 20$ Body $\% 20$ Worn $\% 20$ Camera $\% 20$ Systems.pdf.

${ }^{79}$ Las Vegas Metropolitan Police Department, “GO-009-14 Supp No 2, Aug. 28, 2014,” accessed December 30, 2014, p. 2 , https://static.spokanecity.org/documents/police/accountability/bodycamera/las-vegas-policy.pdf.

${ }^{80}$ Rialto Police Department, "Body Worn Video Systems," LRIS, p. 1, accessed January 14, 2015, http://www.lris.com/wpcontent/uploads/2014/09/Rialto-Policy-on-Body-Cams.pdf.

${ }^{81}$ Peoria Police Department, "Use of Portable Recorders," City of Peoria, p. 1, accessed January 14, 2015, https://www.peoriaaz.gov/uploadedFiles/NewPeoriaAZ/City_Departments/Police_Department/Administration/Policies/Policy 450 Use of_Portable_Recorders.pdf.

${ }_{82}$ Marianna Police Department, "Mobile Video/Audio Recording Equipment," City of Marianna, p. 5, accessed January 14, 2015, http://www.cityofmarianna.com/AgendaCenter/ViewFile/Item/398?fileID=8394.

${ }^{83}$ President's Task Force on 21st Century Policing, Listening Session on Technology and Social Media (2015), written testimony of Johanna E. Miller, Advocacy Director, New York Civil Liberties Union, Cincinnati, OH, accessed January 15, 2015, http://www.nyclu.org/content/testimony-regarding-risks-of-police-body-worn-cameras.

${ }^{84}$ One of the most recent examples of this type of behavior around dashcams can be found here; notably, the obstruction of the footage resulted in the dismissal of charges against the arrested man because of the compromised evidentiary value of the footage. See Julian Kimble, "Footage Shows St. Louis Police Officer Advising Fellow Cops to Shut Dashboard Camera Off During Arrest," Complex, accessed February 18, 2015, http://www.complex.com/pop-culture/2015/02/footage-shows-st-louis-police-telling-officers-to-turn-dashcam-off-during-arrest.
} 
encountered was the fear officers had that the cameras would be used as a tool to monitor their performance; workplace surveillance was the second highest-ranking perception that officers had of the purpose of camera installation. ${ }^{85} \mathrm{~A}$ few agencies, realizing the officers' concerns, solicited their input and experienced a greater acceptance of the technology as a result. ${ }^{86}$

As researcher Dr. Karen Levy has documented in the trucking industry, workers who value their autonomy, and who feel exposed to overt and unwanted levels of workplace surveillance can go to great lengths to resist the surveillance device, including breaking it or blocking its functions through furtive and various creative methods. ${ }^{87}$ While officers are obliged to follow the rules and policies enforced by their departments, there should be a feedback mechanism for officers to express their concerns; conversely, there should be training for officers about the value of body-worn cameras and the ways they can improve their jobs, such that officers willingly use the equipment in accordance with existing policies.

Police officers' privacy concerns as employees should be considered in policies developed around footage retention and use, especially considering that their personal information will be routinely recorded. Their privacy rights under state and federal law, and within the context of any contracts they have as employees, should also be considered in the roll-out of body-worn cameras.

\section{Public Notice and Consent to Be Recorded}

Civil rights and civil liberties advocates, police department leadership, and experts who have studied the issue generally agree that subjects need to know that they are being recorded. The PERF report, the ACLU, ${ }^{88}$ and the Leadership Conference ${ }^{89}$ highlight the need for notice, irrespective of whether state law requires it, unless it is impractical or unsafe for officers to do so. ${ }^{90}$

There is a range of strategies that can be used in tandem to ensure that subjects know they are being recorded. First, a light on the camera may illuminate or begin blinking when recording is in progress. Second, the camera itself may have a front-facing playback screen, which would show subjects what the camera is recording. ${ }^{91}$ Finally, of course, officers may be required to provide notice or obtain consent from subjects.

Beyond notice, the model policies and the Leadership Conference also agree generally that consent should be required (from at least one of the subjects present, if the officer is with a small group of people) in order for police to record in situations where the subjects have a reasonable expectation of privacy, like in their residence. ${ }^{92}$

\footnotetext{
${ }^{85}$ IACP, In-Car Cameras, p. 16.

${ }^{86}$ Ibid, p. 16.

${ }^{87}$ Karen Levy, "Beating the Box: Surveillance and Resistance in the U.S. Trucking Industry," Unpublished manuscript, Princeton

University, Princeton, NJ (2014).

${ }^{88}$ ACLU Report, p. 4.

${ }^{89}$ LCCHR Letter, p. 3.

${ }^{90}$ PERF report, p. 40.

${ }^{91}$ Not all body-worn cameras have this feature, but it is available on body-worn cameras by the brand Reveal. See Reveal, "Body Worn

Video Cameras," Reveal Media, accessed February 6, 2015, http://revealmedia.com/.

92 LCCHR Letter, p. 2, citing LCCHR at 2, citing IACP, Body-Worn Cameras Model Policy, p. 1.
} 
There also needs to be a process whereby officers can opt not to record out of discretion, or particularly, at the request of the subject they are engaging with. While the PERF model policy argues that officers should have the discretion to decide when not to record, particularly at the request of the subject, the Leadership Conference argues that the decision not to record should also require consent from the subject and that "[r]ather than relying solely on an officer's attestation that a subject asked not to be recorded, policies should require the officer to document the subject's request that recording cease, whether by recording the subject's request, obtaining the subject's signature on a standard form, or by another method.",93

Several of the in-use policies that we were able to locate advise officers to tell subjects that they are being recorded either unprompted ${ }^{94}$ or when asked. ${ }^{95}$ Some discuss the issue particularly as it relates to recording in a residence. Burlington, Vermont's department requires officers in a residence to inform parties they are being recorded unless exigent circumstances are present; and suggests they inform those in other locations "whenever possible." ${ }^{6}$ San Diego's policy argues, surprisingly, that "private citizens do not have a reasonable expectation of privacy when talking with police officers during the scope of an officer's official duties...therefore, officers are not required to give notice they are recording." 97

\section{How Long Will Law Enforcement Agencies Retain Footage, and Who Can See it?}

\section{Retention Times and Access to Footage}

There is no clear-cut, universal rule for how long footage should be retained, although a persistent concern across departments is the cost of storage. The broader issues around retention generally center on whether all footage should be retained; or, what types of footage should be flagged for review and retained; the length of time that is reasonable to hold footage that has investigative or evidentiary value; the risk to citizens that a database of footage capturing their daily lives could be a tool for unconstitutional surveillance and monitoring; and that footage can be analyzed to divergent purposes, with differing and prescribed rules for access, review, and analysis. While police departments may be restricted in their retention and access to footage for investigatory purposes (e.g. a policy can dictate that all footage that is not part of investigations should be deleted), supervisors may look to use all sorts of footage as the basis for a review of their department's practices in order to improve training. Moreover, it might be useful for a third-party body that aims to provide more oversight on and insight into police practices to

\footnotetext{
${ }^{93}$ Ibid, pp. 2-3.

94 "Whenever possible and practical, officers should inform individuals that they are being recorded." See Vegas, p. 3; "Officers are encouraged to advise private persons they are recording if the advisement may gain compliance, assist in the investigation, and does not interfere with the investigation or officer safety." See Rialto Police Department, "Body Worn Video Systems," p. 2.

95 "If asked, officers should inform those inquiring that audio-video recording equipment is in use." See Minneapolis Police Department, "MPD Body Camera SOP," City of Minneapolis, November 5, 2014, p. 2, accessed January 14, 2015, http://www.ci.minneapolis.mn.us/www/groups/public/@mpd/documents/webcontent/wcms1p-133495.pdf; "Officers are notrequired to give notice they are recording. However, if asked, officers shall advise citizens they are being recorded." See San Diego Police Department, "Axon Body Worn Cameras," p. 4.

${ }^{96}$ Burlington Police Department, "Department Directive DD14 DigitalImaging, Digital Audio \& Video, and Body Worn Camera Systems," p. 4.

${ }^{97}$ San Diego Police Department, “Axon Body Worn Cameras," p. 4.
} 
access and retain a range of evidentiary and non-evidentiary footage, even while local departmental access to it is restricted.

\section{Footage as Evidence}

"Evidentiary" video is that which is deemed relevant to a particular ongoing investigation. ${ }^{98}$ In some states, state law controls the rules for retention of evidence in investigations. States will sometimes empower designated agencies to determine the minimum time that police departments and other state or local agencies must keep records, sometimes including specific retention rules for evidentiary records in investigations of particular types of crimes. For example, Missouri established the Missouri Local Records Board "to set retention times for local government records," including police. ${ }^{99}$ In New Jersey, the Bureau of Records Management "places all public records on Records Retention Schedules that list the minimum legal and fiscal time periods they must be retained by state and local... agencies." That Bureau created separate schedules for county and municipal police departments. ${ }^{100}$

At the same time, body-worn cameras will likely generate a large volume of video that is not needed for a particular investigation, and model policies propose a range of default rules for such "non-evidentiary" video. The PERF Report does not specify a default rule for how long the body-worn camera video should be retained, stating only that agencies should comply with state mandated retention rules and should make retention times public so that community members know how long they have to request footage. ${ }^{101}$ Likewise, the IACP provides little guidance about how long videos should be stored, stating that videos should be stored "in accordance with state records retention laws." 102 A supplement to the policy notes that retention schedules should account for complaints against the officer and for the costs of storage, and thus should "balance the need for retaining unspecified recordings with the desire to have this information available."103

The ACLU has proposed more stringent default rules for video retention, stating that "data should be retained no longer than necessary for the purpose for which it was collected...retention periods should be measured in weeks not years unless a recording has been flagged [in which case] it would then switch to a longer retention schedule." 104 The Leadership Conference argues that "[s]cheduled, automatic deletion of most footage is vital to prevent these cameras from becoming tools of injustice. Footage should generally be retained as long as it might become relevant to a timely-filed citizen complaint; evidentiary video of crimes, arrests, citations, searches, uses of force and confrontations should be retained in accordance with the general rules for such evidence." 105

\footnotetext{
${ }^{98}$ PERF Report, p. 16.

99 "Police Clerks Record Retention Schedule," Missouri Secretary of State, August 2013, accessed January 15, 2015, p. 2, http://www.sos.mo.gov/archives/localrecs/schedules/pdf/policeclerks.pdf.

100 "Records Retention Schedules," State of New Jersey: Department of the Treasury, accessed January 14, 2015, http://www.nj.gov/treasury/revenue/rms/retention.shtml.

${ }^{101}$ PERF Report, p. 44.

102 IACP, Body-Worn Cameras Model Policy, p. 2.

${ }^{103}$ IACP National Law Enforcement Policy Center, Body-Worn Cameras Concepts and Issues Paper (April 2014), p. 4.

${ }^{104}$ ACLU, "Police Body-Mounted Cameras: With Right Policies in Place, a Win For All," p. 4.

${ }^{105}$ LCCHR Letter, p. 3.
} 
Notably, the line between "evidentiary" and "non-evidentiary" video may be malleable, and could become an important factor in the overall civil rights impact of these new systems. The PERF model policy, for example, defines as "evidentiary" any video that "involves footage of an incident or encounter that could prove useful for investigative purposes, such as a crime, an arrest or citation, a search, a use of force incident or a confrontational encounter with a member of the public" (emphasis added). ${ }^{106}$ Under this standard, there is a risk that all video might be retained because it could, at some future date and for some unforeseen reason, become relevant to an investigation. One underlying assumption of proposals from the civil rights and civil liberties community is that only a small subset of video will be deemed evidentiary, and only for reasons specifically tailored to that footage.

\section{Categorized and Uncategorized Video}

Several departments whose policies we examined differentiate between categorized video, which may be evidence in the future, and uncategorized video. Retention times for the uncategorized video range from 14 days in Grand Forks North Dakota ${ }^{107}$ to two years in New Orleans. ${ }^{108}$ Categorized video is often retained according to its category. For example, Las Vegas keeps video labeled "homicide" for seven years, "misdemeanor citation" video for one year, and "use of force" video for 90 days. ${ }^{109}$ The disparity in retention times is just one example of how there are few clear policy trends amongst police departments using body-worn cameras. Moving forward, law enforcement agencies should consider striking a balance that takes into account both practical and ethical considerations of retaining video data.

\section{Lengthy Retention Times and Civil Rights}

One of the reasons lengthy retention times could pose a threat to civil liberties is that video could be used for long-term tracking of individuals. If combined with technologies such as facial recognition systems, which identify individuals by matching images of their faces against database records, footage could be used to build a repository of information on individuals, regardless of whether they are suspected of a crime (even if the underlying footage is not retained, there remains some risk that a facial recognition technology may be used in real time to create non-video records of subjects' whereabouts and movements). Constitutional lawyer Shahid Buttar has warned that constant video footage from body-worn cameras could lead to monitoring anyone or any police encounter "without the individual basis for suspicion constitutionally required to justify a police search." ${ }^{110}$ It could also fuel a rise in mass incarceration if footage is used to routinely convict people of minor crimes like jaywalking. ${ }^{111}$

\footnotetext{
${ }^{106}$ PERF Report, p. 16.

107 Grand Forks Police Department, "Directive: Body-Worn Camera Recording Equipment," Grand Forks Herald, revised November 26, 2014, p. 3, accessed January 14, 2015, http://www.grandforksherald.com/sites/default/files/4113.pdf.

${ }^{108}$ New Orleans Police Department, "New Orleans Police Department Policy Manual, Body-Worn Camera Policy 447," p. 8, accessed January 14, 2015, http://www.fopno.com/uploads/files/Policy\%20447\%20-\%20PR447\%20\%20Body\%20Worn\%20Camera\%20EFF\%203-30-14.pdf.

${ }^{109}$ Vegas, p. 9.

110 "The Quiet Horrors of House Arrest, Electronic Monitoring, and Other Alternative Forms of Incarceration," Mother Jones, January 22, 2015, accessed January 26, 2015, http://www.motherjones.com/politics/2015/01/house-arrest-surveillance-state-prisons.

${ }^{111}$ Ibid.
} 
Potentially, police departments would also be able to retroactively comb through years' worth of footage to find incriminating evidence to use as leverage against particular individuals. ${ }^{112}$

A cautionary example can be found in the excessively lengthy retention times observed by private companies that manage databases of license plate numbers (such as the National Vehicle Location Service). This data is collected via Automated License Plate Readers (ALPRs), which cull license plate numbers from surveillance photographs. ${ }^{113}$ These databases, which are available to law enforcement agencies, are also used for commercial data mining ${ }^{114}$ and in some cases are retained for five or more years regardless of whether the driver is suspected of any crime. ${ }^{115}$

\section{Rules for Viewing By Police}

After body-worn camera video is entered into a database, there is a significant question about who, both inside and outside police departments, may view the footage. the ACLU argues that "the use of recordings should be allowed only in internal and external investigations of misconduct, and where the police have reasonable suspicion that a recording contains evidence of a crime. Otherwise, there is no reason that stored footage should even be reviewed by a human being before its retention period ends and it is permanently deleted." 116

The PERF report argues that officers should be allowed to use footage before writing an incident report, suggesting that "reviewing footage will help officers remember the incident more clearly, which leads to more accurate documentation of events." 117 The Leadership Conference disagrees, asserting that officers should not see the footage before filing their own report to avoid a situation where two seemingly independent pieces of evidentiary accounts, the officer's recollection and what's on the video, are actually based off one another. An officer may reasonably conform their recollection to what is evident on the video, but video can only offer a partial perspective on how events unfold. ${ }^{118}$ Therefore, it is more valuable to have valid, competing accounts, or at the very least, not to give the impression to defendants or to the court that the report and the footage are independent accounts.

Six of the eleven in-use department policies that we examined explicitly state that officers should be able to view footage from their body-worn cameras either generally or before writing an incident report. Rialto, Peoria, and San Diego generally state that officers may review their own footage. ${ }^{119}$ Other jurisdictions specify that officers should or may review their own footage

\footnotetext{
112 Rory Carroll, "California Police Use of Body Cameras Cuts Violence and Complaints,” accessed February 6, 2015, http://www.theguardian.com/world/2013/nov/04/california-police-body-cameras-cuts-violence-complaints-rialto.

113 "Automated License Plate Readers (ALPR)," Electronic Frontier Foundation, accessed January 20, 2015, https://www.eff.org/foia/automated-license-plate-readers.

114 "You Are Being Tracked: How License Plate Readers Are Being Used to Record Americans' Movements," American Civil Liberties Union, July 2013, accessed January 12, 2015, https://www.aclu.org/technology-and-liberty/you-are-being-tracked-how-license-platereaders-are-being-used-record.

115 “ACLU Battles Connecticut Law Enforcement Agencies Over Retention Of Licence Plate Reader Data,” Techdirt, accessed February 2, 2015, https://www.techdirt.com/articles/20140309/10300326501/aclu-battles-connecticut-law-enforcement-agencies-over-retentionlicence-plate-reader-data.shtml.

${ }_{116}$ ACLU, "Police Body-Mounted Cameras: With Right Policies in Place, a Win For All," p. 5.

${ }^{117}$ PERF Report, p. 45.

${ }^{118}$ LCCHR Letter, p. 3.

${ }^{119}$ Rialto Police Department, “Body Worn Video Systems,” p. 4; Peoria Police Department, "Use of Portable Recorders,” p. 3; San

Diego Police Department, “Axon Body Worn Cameras," p. 9.
} 
while creating reports. Las Vegas police officers are "encouraged" to view their recordings when "completing an investigation and preparing official reports," in order to maintain accuracy. ${ }^{120}$ Likewise, Minneapolis police "should" review the video before making reports" ${ }^{121}$ and New Orleans officers "may review his or her own [body-worn camera] recording to help ensure accuracy and consistency of accounts." 122

The PERF Report and the IACP model policy permit supervisors to view footage for investigative, supervisory or training purposes, with clear policies on the circumstances when supervisors are authorized to examine an officer's footage. Common situations in which supervisors may need to review footage include... [1] to investigate a complaint against an officer ... [2] to identify videos for training purposes ... [3] [or to investigate officers who have a] pattern of allegations of verbal or physical abuse."123 The IACP asserts that supervisors should "randomly review [body-worn camera] recordings to ensure ... that officers are using the devices appropriately and in accordance with policy and to identify any areas in which additional training or guidance is required." "124 Alternatively, the Constitution Project favors another approach, arguing that "an agency's internal audit unit, not an officer's direct chain of command, should conduct random review of footage to monitor compliance with the program." 125

Several of the actual policies we found address the circumstances under which supervisors may review footage. New Orleans states, "a supervisor may review specific [body-worn camera] media or data for the purpose of training, performance review, critique ...or other articulable reason." 126 Similarly, Grand Forks allows supervisors to review recordings "for training purposes and as a means of monitoring officer performance." ${ }^{127}$ Las Vegas and Rialto offer supervisors access to video on a more limited basis. In Las Vegas, "supervisors do not have direct access to an officer's [body-worn camera] video" and may only view video when investigating force, during internal investigations, and to address "clearly documented performance issue [s]." 128 In Rialto, "supervisors are to review recordings only as directed by the Chief of Police." 129

\section{Rules for Public Access}

Public records laws are intended to grant citizens access to government records. ${ }^{130}$ This raises a question of whether body-worn camera video is a public record, and if so, whether it may or must be disclosed. The answer to this question will vary by state, as each state has its own public

\footnotetext{
${ }^{120}$ Vegas, p. 6.

${ }^{121}$ Minneapolis Police Department, "MPD Body Camera SOP," p. 4.

${ }^{122}$ New Orleans Police Department, "New Orleans Police Department Policy Manual, Body-Worn Camera Policy 447," Fraternal Order of Police New Orleans, p. 9, accessed January 14, 2015, http://www.fopno.com/uploads/files/Policy\%20447\%20-\%20PR447\%20\%20Body\%20Worn\%20Camera\%20EFF\%203-30-14.pdf.

${ }_{123}$ PERF Report, p. 45-6.

${ }^{124}$ IACP, Body-Worn Cameras Model Policy, p. 2.

${ }^{125}$ The Constitution Project Committee on Policing Reforms, "The Use of Body-Worn Cameras by Law Enforcement: Guidelines for Use and Background Paper," The Constitution Project, January 28, 2015, accessed February 13, 2015,

http://www.constitutionproject.org/wp-content/uploads/2015/02/TCP-The-Use-of-Police-Body-Worn-Cameras.pdf.

${ }^{126}$ New Orleans Police Department, "New Orleans Police Department Policy Manual, Body-Worn Camera Policy 447," p. 9.

${ }^{127}$ Grand Forks Police Department, "Directive: Body-Worn Camera Recording Equipment," p. 3.

${ }^{128}$ Vegas, p. 6.

${ }^{129}$ Rialto Police Department, "Body Worn Video Systems," p. 2.

${ }^{130}$ PERF Report, p. 17.
} 
records law. ${ }^{131}$ Some states also have exceptions or exemptions to their public records law that prevent disclosure of certain records, like ongoing criminal investigation records or law enforcement records more generally. For example, Minnesota's public records law states that all data from government entities shall be public unless classified by statute as nonpublic or protected nonpublic, ${ }^{132}$ but that law goes on to say that generally, "investigative data collected or created by a law enforcement agency in order to prepare a case against a person ... are confidential or protected nonpublic while the investigation is active." 133

According to the ACLU, policymakers must "carefully balance," "the need for government oversight and openness, and privacy," when creating policies about public disclosure. ${ }^{134}$ To do that, it suggests flagging those videos "for which there is the highest likelihood of misconduct" 135 and redacting video "when feasible" and asserts that unredacted video should only be publicly disclosed with the consent of the subject. ${ }^{136}$ However, redacted video and unredacted flagged video should be subject to disclosure, ${ }^{137}$ and according to the Leadership Conference, redacted footage should be made available for non-commercial public interest purposes, with the right protections for witnesses and victims. ${ }^{138}$ PERF suggests that agencies should have clear protocols for releasing recorded data to the public, consistent with public disclosure laws. ${ }^{139}$

\section{How Is Footage Secured? Cloud Storage of Video Data}

Some body-worn camera manufacturers offer a secure cloud storage service, while others, such as Wolfcom, only provide internal management software. ${ }^{140}$ Among 40 police departments surveyed by PERF in 2014, all reported that they stored their video on a third party cloud database or an in-house server managed by the department. ${ }^{141}$ Two of the most widely purchased camera models, ${ }^{142}$ manufactured by TASER and VIEVU, offer cloud storage service at additional cost. ${ }^{143}$ While cloud storage reduces the amount of time and resources that law enforcement agencies must devote to managing video data, it also shifts many of the security responsibilities onto a third party. For this reason, it is important that third party vendor contracts and policies on matters such as security and access should be aligned with the internal policies of

\footnotetext{
${ }^{131}$ Cheryl Cooper, "Sending the Wrong Message: Technology, Sunshine Law, and the Public Record in Florida," 39 Stetson L. Rev. 411 , 413 (2010).

${ }^{132}$ Minnesota Government Data Practices, Section 13.03 Subdivision 1 “Access to Government Data," accessed February 9, 2015, https://www.revisor.mn.gov/statutes/?id=13.03.

${ }^{133}$ Minnesota Government Data Practices, Section 13.82 Subdivision 7 “Criminal Investigative Data,” accessed February 9, 2015, https://www.revisor.mn.gov/statutes/?id=13.82.

${ }^{134}$ ACLU, "Police Body-Mounted Cameras: With Right Policies in Place, a Win For All," p. 5.

135 Ibid, p. 5.

${ }^{136}$ Ibid, p. 5 .

${ }^{137}$ Ibid, p. 5.

${ }^{138}$ LCCHR Letter, p. 3

${ }^{139}$ PERF Report, p. 46.

140 "Wolfcom Management Software With GPS," Wolfcom USA, accessed January 30, 2015, http://www.wolfcomusa.com/police_camera_management_software/police\%20camera\%20backend.html.

${ }^{141}$ PERF Report, P. 15.

${ }^{142}$ White (2014) conducted a literature review and identified VIEVU and TASER International as the most widely cited camera manufacturers. See White, Assessing the Evidence, p. 12.

${ }^{143}$ For TASER cloud storage plans, see "Evidence.com Plans," Evidence.com, accessed February 9, 2015, https://www.evidence.com/pricing; For VIEVU cloud storage plans, see "Veripatrol Cloud," VIEVU, accessed February 9, 2015, http://www.vievu.com/vievu-products/software/\#veripatrol-cloud.
} 
the law enforcement agencies. The PERF report advises police departments to consult with prosecutors and legal experts on whether the vendor's policies are "in compliance with all relevant laws and adequately preserve evidentiary chain of custody."144

The IACP cautions police departments generally to ensure that videos are "securely stored." 145 Concerning cloud computing, the IACP has developed a set of guidelines which law enforcement agencies should consider when drafting a contract with a third party vendor. The IACP recommends the following rules: (1) storage service should comply with the Criminal Justice Information Services Security Policy; ${ }^{146}$ (2) law enforcement agencies must retain ownership of all data; (3) the vendor should not data mine or share data without explicit consent from law enforcement agencies; (4) the agency should be permitted to conduct audits on the cloud service provider's performance, use, and compliance with the agreed policy; (5) the data should be portable and interoperable with other operating systems without compromising security; (6) law enforcement data should be kept secure and separate from the provider's consumer cloud services; (7) agencies should include provisions to ensure continuity of terms of agreement "irrespective of the commercial viability of the service provider or changes in operations, ownership, structure, technical infrastructure, and/or geographic location;" (8) the vendor must take all necessary steps to maintain the confidentiality of law enforcement data; (9) the vendor must ensure that data is reliably available to law enforcement; and (10) agencies should calculate a cost-benefit analysis based on the "lifetime value" of cloud storage versus inhouse storage. ${ }^{147}$

Similar to the IACP's recommendations, both the NYCLU and the Constitution project urge caution when dealing with third party vendors. The NYCLU remarks that contracts with storage providers should have language to protect against potential misuse, and access to footage should be limited to only essential employees of the storage company. ${ }^{148}$

Major camera manufacturers offer cloud storage via services that comply with the FBI's CJIS security policies. The CJIS policy was created to provide a set of minimum standards for the "creation, viewing, modification, transmission, dissemination, storage, or destruction of CJI [Criminal Justice Information]" including, but not limited to, the use of cloud storage services. ${ }^{149}$ The policy provides detailed guidance on recommended practices such as security awareness training of all personnel with access to stored data, ${ }^{150}$ developing a protocol for security incident response, ${ }^{151}$ auditing and accountability controls to log relevant actions from authorized users, ${ }^{152}$ identification and authentication procedures, ${ }^{153}$ configuring access restrictions, ${ }^{154}$ secure

\footnotetext{
${ }^{144}$ PERF Report, p. 15.

${ }^{145}$ IACP, Body-Worn Cameras Model Policy, p. 2.

${ }^{146}$ See “CJIS Security Policy, version 5.3 8/4/2014," Federal Bureau of Investigation, August 4, 2014, accessed February 9, 2015, http://www.fbi.gov/about-us/cjis/cjis-security-policy-resource-center.

147 "IACP Guiding Principles on Cloud Computing in Law Enforcement," CJIS Solutions, accessed January 30, 2015, http://www.cjissolutions.com/files/2013/09/PC_tips_IACP_Cloud_computing.pdf.

${ }_{148}$ The Constitution Project Committee on Policing Reforms, "The Use of Body-Worn Cameras by Law Enforcement: Guidelines for Use and Background Paper," The Constitution Project, January 28, 2015, p. 5, accessed February 13, 2015,

http://www.constitutionproject.org/wp-content/uploads/2015/02/TCP-The-Use-of-Police-Body-Worn-Cameras.pdf.

${ }_{149}$ CJIS Security Policy, p. 1.

${ }^{150}$ Ibid, p. 20.

${ }^{151}$ Ibid, p. 23.

152 Ibid, p. 26.

${ }^{153}$ Ibid, p. 34.

${ }^{154}$ Ibid, p. 47.
} 
disposal of physical/digital media, ${ }^{155}$ conducting formal audits to ensure compliance, ${ }^{156}$ and screening personnel. ${ }^{157}$ An appendix on cloud computing aligns with the IACP guidelines regarding practices such as asserting ownership of all data, putting in place auditing mechanisms, protecting data and ensuring its availability. Additionally, the policy recommends ensuring that the cloud provider has a transparent response process in response to incidents. ${ }^{158}$

Among the services that comply with CJIS Security policy are TASER International, which offers storage via Evidence.com using Amazon Web Services, ${ }^{159}$ and VIEVU, which offers the VERIPATROL video management platform using Microsoft's Azure Government Cloud. ${ }^{160}$ Many systems also track all activity and maintain an audit log. ${ }^{161}$

However, police departments should consider whether cloud storage services can be customized to comply with their specific policies. For example, officers in the Oakland Police Department are only allowed to review footage of use of force after they have submitted a report documenting the incident according to their internal policy, ${ }^{162}$ so it would make sense if their vendor offered customizable controls that would regulate officer access before that point. Evidence.com offers customizable role-based permission management settings, ${ }^{163}$ but those settings may not be sophisticated enough to align with agencies' more complex access and control need.

Finally, as the IACP guidelines advise, police departments should consider the risk that data may be used for non-law-enforcement functions, or without being governed by the same principles and policies that apply to police use of that data. Hanni Fakhoury, a staff attorney for the Electronic Frontier Foundation (EFF), notes the lack of federal restrictions safeguarding data and points to the possibility for third-party data mining of body-worn camera footage. ${ }^{164}$ This can pose concerns for privacy because there is very little control over what is done with the data once it leaves the hands of law enforcement.

While the police departments consulted by PERF did not report any issues with using third party vendors to manage recorded data, ${ }^{165}$ it nevertheless suggests that police agencies that opt

\footnotetext{
${ }^{155}$ Ibid, p. 49.

${ }^{156}$ Ibid, p. 60

${ }^{157}$ Ibid, p. 62

${ }^{158}$ Ibid, Appendix, pp. G-27-G29.

159 "Security," EVIDENCE.com, accessed February 2, 2015, https://www.evidence.com/articles/security. For Amazon Web Service's compliance with CJIS Security Policy, see “AWS | US Federal Government," Amazon Web Services, Inc., accessed February 9, 2015, http://aws.amazon.com/federal/.

160 "VIEVU Works With Microsoft Azure Government Cloud to Enhance Public Safety Cloud Platform for Body Cameras," GlobeNewswire News Room, November 11, 2014, http://globenewswire.com/news-release/2014/11/11/681983/10107560/en/VIEVUWorks-With-Microsoft-Azure-Government-Cloud-to-Enhance-Public-Safety-Cloud-Platform-for-Body-Cameras.html; For Microsoft Azure's compliance with CJIS Security Policy, see "Microsoft Azure Government Meets Criminal Justice Information Services (CJIS) Requirements," Microsoft Azure, accessed February 10, 2015, http://azure.microsoft.com/blog/2014/12/18/microsoft-azure-governmentmeets-criminal-justice-information-services-cjis-requirements.

${ }^{161}$ White, Assessing the Evidence, p. 33.

162 "Portable Video Management System," Oakland Police Department, March 5, 2014, accessed February 1, 2015, https://www.aclu.org/sites/default/files/assets/mar_14_pdrd_policy.pdf.

163 "Evidence.com Security," TASER International, accessed February 1, 2015, https://taser-international.cdn.prismic.io/taserinternational\%2F58eb023c-674d-45a7-a0ee-df77059aalc1_evidence+com+security+-+us+v3.pdf.

${ }^{164}$ Jacob Siegel, "Your Arrest Video Is Going Online. Who Will See It?” The Daily Beast, September 11, 2014, accessed January 12, 2015, http://www.thedailybeast.com/articles/2014/09/11/we-re-giving-police-body-cameras-but-who-s-controlling-their-footage.html. ${ }^{165}$ PERF Report, p. 45.
} 
for cloud storage should set out explicit rules and needs when entering into contracts. ${ }^{166}$ The Leadership Conference agrees, stating "agencies should be free to contract with vendors to assist in the management of footage, where the vendor acts on behalf of the police agency and is subject to the same restrictions." ${ }^{167}$ It may be wise for an organization, such as the IACP's Technology Technical Assistance Program, to create a standard Terms of Service (ToS) agreement that local police departments can adopt for their own use could help empower them in their relations with vendors, while ensuring that the deployment of police-worn body cameras is done in the context of sound and feasible policy. The agreement could address issues of footage retention, security and risk management, and media and data failure policies.

\section{When Can Biometrics Be Collected or Used?}

The use of body-worn cameras has already begun to intersect with other technologies such as facial recognition systems. Serious concerns for privacy may arise if police use of body-worn cameras to scan public spaces to identify individuals with outstanding arrest warrants. This section provides a brief overview of the current landscape of biometric measurement in law enforcement as it pertains to video surveillance.

The Federal Bureau of Investigation defines biometrics as the "measurable biological (anatomical and physiological) or behavioral characteristics used for identification of an individual." Distinctive markers such as fingerprints, facial features, DNA, voice, and iris scans can be used to identify individuals, usually by matching them against a pre-existing database. ${ }^{168}$ Today, some law enforcement and intelligence agencies rely on computer-based recognition software. Facial recognition technology can scan videos or still images on a mass scale and in real time (or in retrospect) without the subject being aware or granting consent. ${ }^{169}$ For example, during the 2001 Super Bowl held in Tampa Florida, Tampa police used mass surveillance cameras and facial recognition technology to scan the faces of people in attendance and compare them to criminal and terrorist databases. ${ }^{170}$ In July 2014, the Leicestershire Police in the UK began testing the NeoFace System, a facial recognition software, to scan CCTV and body-worn camera footage. However, when the system found a match, it turned out to be the wrong person $45 \%$ of the time. ${ }^{171}$ Outside of a controlled environment, facial recognition is prone to inaccuracy and a high false-positive rate. ${ }^{172}$

\footnotetext{
${ }^{166}$ Ibid, p. 16.

${ }^{167}$ LCCHR Letter, pp. 3-4.

168 "Fingerprints \& Other Biometrics," Federal Bureau of Investigation, accessed January 23, 2015, http://www.fbi.gov/aboutus/cjis/fingerprints biometrics/fingerprint_biometrics.

169 "Biometrics for Intelligence-Led Policing: The Coming Trends," Police Chief Magazine, accessed January 28, 2015, http://www.policechiefmagazine.org/magazine/index.cfm?fuseaction=display_arch\&article_id=2358\&issue id=42011.

${ }^{170}$ Jay Stanley and Barry Steinhardt, American Civil Liberties Union, Drawing a Blank: The failure of facial recognition technology in Tampa, Florida (January 3, 2002), p. 1, http://www.epic.org/privacy/surveillance/spotlight/1105/aclu0302.pdf (originally available at http://archive.aclu.org/issues/privacy/drawing_blank.pdf).

171 "Leicestershire Police trial facial recognition software," BBC News, July 15, 2014, accessed January 13, 2015, http://www.bbc.com/news/uk-england-leicestershire-28307938.

172 "The Limits of Facial Recognition,” PBS NOVA Next, accessed January 13, 2015, http://www.pbs.org/wgbh/nova/next/tech/thelimits-of-facial-recognition/.
} 
Some U.S. police departments have already begun using facial recognition to scan CCTV surveillance footage against mug shot databases. Both Seattle ${ }^{173}$ and Chicago ${ }^{174}$ have begun implementing facial recognition on CCTV footage. In Seattle, the ACLU has expressed concern over the collection of information on people not suspected of criminal activity, ${ }^{175}$ a practice that will likely become a major privacy concern as the technology spreads. Disparities between image databases in use across police departments will also present obstacles in the efficacy of facial recognition, as individual records may exist in one database but not another. While body-worn cameras facilitate surveillance on a smaller scale than CCTV footage, many of the same privacy risks will become salient for both.

Recent advances in technology are also making possible increasingly invasive extraction of biometric information from video footage. In 2014, a security expert was able to replicate a German politician's fingerprint based on a high-resolution photograph of her hand. ${ }^{176}$ Researchers have also found a way to identify the person wearing a body-worn camera by comparing biometric markers such as camera motion (like shakes) and stride length, meaning that a person filming will not necessarily remain anonymous. ${ }^{177}$

These advances in technology may have both positive and negative implications. The dominant concern is that legal rights to privacy are struggling to keep up with these changes. Although the fourth amendment likely protects biometric information such as DNA or fingerprints from collection without due cause, ${ }^{178}$ in 2013 the Supreme Court ruled that police could take DNA samples from individuals arrested in connection to serious crimes. ${ }^{179}$ Laws are even less clear on when, if ever, something as publicly visible as the human face can be protected from automatic identification. ${ }^{180}$ Moreover, there is an increasingly blurred line between collection of criminal and non-criminal biometric data. Law enforcement bodies such as the NYPD's Facial Recognition Unit have begun combing photos on social media platforms to identify suspects. ${ }^{181}$ The FBI is also in the process of building the Next Generation Identification program (NGI), a large-scale biometric database covering faces, fingerprints, and other identifiers. This database will store both criminal and non-criminal information, such as photos

\footnotetext{
${ }^{173}$ Josh Sanburn and Alexandra Sifferlin, "Seattle Police to Use Facial Recognition Software,” Time, March 14, 2014, accessed January 28, 2015, http://time.com/25605/seattle-police-to-use-facial-recognition-software/.

174 "Chicago Police Start Using Facial-Recognition Software to Arrest Suspects," RT News, accessed February 6, 2015, http://rt.com/usa/chicago-police-cctv-surveillance-135/.

175 Josh Sanburn and Alexandra Sifferlin, "Seattle Police to Use Facial Recognition Software."

${ }^{176}$ Alex Hern, "Hacker Fakes German Minister's Fingerprints Using Photos of Her Hands," The Guardian, accessed January 29, 2015, http://www.theguardian.com/technology/2014/dec/30/hacker-fakes-german-ministers-fingerprints-using-photos-of-her-hands.

${ }_{177}$ Megan Geuss, "4 Seconds of Body Cam Video Can Reveal a Biometric Fingerprint, Study Says," Ars Technica, December 16, 2014, http://arstechnica.com/tech-policy/2014/12/4-seconds-of-body-cam-video-can-reveal-a-biometric-fingerprint-study-says/.

178 "A search or seizure is ordinarily unreasonable in the absence of individualized suspicion of wrongdoing," City of Indianapolis v. Edmond, 531 U.S. 32, 37 (2000). The Supreme Court ruled that collecting DNA evidence is a search. "It can be agreed that using a buccal swab on the inner tissues of a person's cheek in order to obtain DNA samples is a search." Maryland v. King, 133 S. Ct. 1958 , 1968-69 (2013). Thus, conducting a "search" without reasonable suspicion will likely violate the Fourth Amendment.

${ }^{179}$ Adam Liptak, "Supreme Court Says Police Can Take DNA Samples," The New York Times, June 3, 2013, sec. U.S., accessed January 23, 2015, http://www.nytimes.com/2013/06/04/us/supreme-court-says-police-can-take-dna-samples.html.

${ }^{180}$ Kyle Chayka, “The Facial Recognition Databases Are Coming. Why Aren't the Privacy Laws?,” The Guardian, accessed January 23 , 2015, http://www.theguardian.com/commentisfree/2014/apr/30/facial-recognition-databases-privacy-laws.

181 "High-Tech NYPD Unit Tracks Criminals Through Facebook and Instagram Photos - New York City," DNAinfo New York, accessed January 29, 2015, http://www.dnainfo.com/new-york/20130325/new-york-city/high-tech-nypd-unit-tracks-criminals-through-facebookinstragram-photos/.
} 
and fingerprints submitted to employers. ${ }^{182}$ One concern raised by the Center for Democracy and Technology is that police departments could draw body-worn camera footage from databases and use facial recognition to catalogue attendees of protests or political rallies. ${ }^{183}$

According to the PERF Report, "Body-worn cameras raise many privacy issues that have not been considered before. Unlike many traditional surveillance methods, body-worn cameras can simultaneously record both audio and video and capture close-up images that allow for the potential use of facial recognition technology." "184 Given these privacy risks, the Leadership Conference cautions: "biometric evaluation of footage must be strictly limited to narrow, welldefined uses, and subject to judicial authorization. ${ }^{185}$ Moving forward, the civil rights community will have to pay particular attention to the growing privacy risks that may be created as the use of body-worn cameras becomes tied to other advanced technologies.

\section{Cameras Cannot Tell the Full Story}

Body-worn cameras not only have the potential to increase transparency in police interactions, but also may provide important evidence in civil and criminal matters. However, the idea that cameras are able to capture the full story should be taken with caution. Video recordings are often treated "as if they are transparent windows onto reality rather than curated, edited, visual arguments." In the courtroom, there is often "a strong belief that video is a singularly powerful and unambiguous source of proof." "186 Yet footage sometimes fails to provide important context, and can be subject to biases and varying interpretations. In some cases, it may require special training to interpret the content of what is captured in recording. Below are some considerations on how the selective nature of body-worn camera footage may impact how it is perceived and used as evidence.

\section{Limits to the Camera's Point of View}

While some body-worn camera models provide wide-angle shots and high-resolution imaging, there is a limit to how much can be captured on video. Evaluators will need to "overcome the inherent limits of the video's frame," as angle, focus, or the width of the shot may impact what is captured. ${ }^{187}$ Moreover, body-worn cameras present footage from an officer's perspective, which itself varies depending on the camera's mount and vantage point, and may not capture what other witnesses are seeing. Even the way in which the officer moves his body will affect what is visible on the footage. While models such as TASER's AXON can provide additional context with a 30 -second buffer prior to recording, ${ }^{188}$ video cannot capture the full

\footnotetext{
182 "Privacy Fears over FBI Database," BBC News, April 15, 2014, accessed January 23, 2015, http://www.bbc.com/news/technology$\underline{27037009}$.

183 "How to Police the Police: What Rules Should Govern Police Use of Body Cameras?" Center for Democracy \& Technology, November 26, 2014, accessed January 28, 2015, https://cdt.org/blog/how-to-police-the-police-what-rules-should-govern-police-use-ofbody-cameras/.

${ }^{184}$ PERF Report, p. 11.

${ }^{185}$ LCCHR Letter, p. 3

${ }^{186}$ Howard M. Wasserman, “Orwell's Vision: Video and the Future of Civil Rights Enforcement.” Md. L. Rev. 68 (2008), p. 600.

${ }^{187}$ Ibid, p. 620.

188 “AXON body on-officer video,” TASER International, accessed January 26, 2015, http://www.taser.com/products/on-officervideo/axon-body-on-officer-video.
} 
circumstances of what happens outside the camera's view ${ }^{189}$ or what events prompted the events being recorded.

With cell phones being used to photograph or record police, ${ }^{190}$ other witnesses may capture different perspectives and different context from other vantage points. Thus, it is important to recognize that the interpretations of events captured by the cameras can be both challenged and supported by other forms of testimony, such as civilians' eyewitness accounts, or civilian camera footage.

\section{Perspective and Bias in Video Interpretation}

In 2004, a report on In-Car Cameras (dashcams) by the International Association of Chiefs of Police concluded that there was a major gap between the capabilities of the cameras, and what the public expected they could achieve; it recommended that the limitations of the cameras be addressed in trial proceedings so that "the jury does not have unreasonable expectations of what the video evidence can provide." ${ }^{191}$ Similarly, there is a gap between expectations about what video footage represents - an unbiased, third-party viewpoint - and the biases inherent to video interpretation.

The In-Car Camera report also asserted that the "the greatest single value of the in-car camera is that it is more and more frequently called upon to speak for the officer when they cannot speak for themselves." 192 However, video evidence cannot necessarily speak for itself.

\section{Case Study}

A study conducted by Yale law professor Dan Kahan and his colleagues demonstrated how interpretation of video evidence can vary widely based on factors like race, political affiliation, and income. ${ }^{193}$ The case examined, Scott v. Harris, involved dashcam footage of a police chase in which an officer deliberately rear-ended the plaintiff, who became a quadriplegic as a result. The plaintiff then sued the officer, alleging that he had used excessive force. ${ }^{194}$ The officer claimed he was justified in rear-ending the plaintiff because the plaintiff's reckless driving constituted a threat to public safety. ${ }^{195}$ However, the plaintiff denied that his driving threatened public safety. The Supreme Court held that the officer should have prevailed on summary judgment because the plaintiff"s "version of events is so utterly discredited by the [video footage] that no reasonable jury could have believed him" and the lower court "should have

\footnotetext{
${ }^{189}$ Wasserman, “Orwell’s Vision,” p. 620.

${ }^{190}$ See Tim White for an account of a citizen recording a police officer talking on his cell phone and cursing. "Mass. Man Arrested After Recording Officer in Street," WPRI, March 6, 2014, accessed January 27, 2015, http://wpri.com/2014/03/06/massachusetts-manarrested-after-recording-police-officer-in-street; See Susan Sharon for an account of a couple who were arrested after recording police officers conduct a field sobriety test. "Maine Couple Sues Portland Police After Arrest for Cell Phone Recording," MPBN News, September 16, 2014, accessed January 28, 2015, http://news.mpbn.net/post/maine-couple-sues-portland-police-after-arrest-cell-phonerecording.

${ }^{191}$ IACP/COPS Technology Technical Assistance Program, In-Car Cameras (Alexandria, Va.: International Association of Chiefs of Police, 2005), p. 54, at http://www.theiacp.org/portals/0/pdfs/InCarCamera.pdf.

192 Ibid, p. 47.

${ }^{193}$ Dan M. Kahan, et. al., Whose Eyes Are You Going to Believe? Scott v. Harris and the Perils of Cognitive Illiberalism, 122 Harv. L. Rev. 837, 838 (2009).

${ }^{194}$ Scott v. Harris, 550 U.S. 372, 372 (2007).

${ }^{195}$ Ibid, p. 383.
} 
viewed the facts in the light depicted by the videotape."196 However, in Justice Steven's dissent (which interpreted the video differently and agreed with the lower court that that the case should not be decided against the plaintiff in summary judgment), the majority posted the dashcam video of the chase online and wrote "we are happy to allow the videotape to speak for itself."197

Kahn and his associates accepted the Supreme Court's invitation and invited the public and invited 1,350 diverse members of the public to watch the video from Scott v. Harris and interpret: (1) whether the speeding motorist had posed a public threat, and (2) whether the officer was justified in rear-ending the motorist to stop him. ${ }^{198}$ The results of the study showed that interpretation of the video varied widely in both regards. On the whole, African-Americans, lowincome subjects, and Democrats were more likely to side with the plaintiff than with the Court. ${ }^{199}$

\section{Unconscious Bias}

Existing biases can also manifest in interpretation of body-worn camera footage. Various studies have highlighted the biases that shape people's judgments and how interpersonal interactions can draw on conscious and unconscious stereotypes. ${ }^{200}$ For example, a European Parliament study examining which people CCTV camera operators in the UK chose to focus on found that the "young, the male and the black were systematically and disproportionately targeted" regardless of whether there was any indication of criminal behavior. ${ }^{201}$ A 2014 study found a "superhumanization bias," which showed that subjects were more likely to perceive black, particularly male, individuals as having less sensitivity to pain and greater physical strength and aggression than any other group. ${ }^{202}$ Another study found that subjects were more likely to read emotions like anger into black male faces than faces of people of other races. ${ }^{203}$ Reviewers of body-worn camera video resulting from police shootings will need to assess how much danger the officer faced to determine whether use of force was justified. Accordingly, there is a risk that reviewers' biases may emerge. They may be quicker to read aggressive or violent intent in minority subjects' body language or behavior, and as a result will be more inclined to find use of force justified. Accordingly, reviewers will need to be more sensitive about how perspective can affect the ways they interpret actions based on visual evidence.

\footnotetext{
${ }^{196}$ Ibid, pp. 380-1.

${ }^{197}$ Ibid, p. 378, n. 5.

${ }^{198}$ Scott v. Harris, pp. 857-858.

${ }^{199}$ Ibid, p. 841.

${ }^{200}$ For perception studies on conscious and unconscious racial biases, see Payne, B. K., "Prejudice and perception: The role of automatic and controlled processes in misperceiving a weapon," Journal of Personality and Social Psychology, 81 (2001): 181-192; C.A. Cottrell and S. L. Neuberg, "Different emotional reactions to different groups: A sociofunctional threat-based approach to "prejudice." Journal of Personality and Social Psychology, 88 (2005): 770-789; Phillip Atiba Goff et al.,"Not yet human: Implicit knowledge, historical dehumanization, and contemporary consequences," Journal of Personality and Social Psychology, 94 (2008): 292-306.

${ }^{201}$ Clive Norris and Gary Armstrong, "The unforgiving eye: CCTV surveillance in public space." Report for the Centre for Criminology and Criminal Justice, Hull University (1997).

${ }^{202}$ Adam Waytz, Kelly Marie Hoffman, and Sophie Trawalter, “A Superhumanization Bias in Whites’ Perceptions of Blacks.” Social Psychological and Personality Science, 2014.

${ }^{203}$ Kurt Hugenberg and Galen V. Bodenhausen, "Facing implicit prejudice and the perception of facial threat." Psychological Science 14, no. 6 (2003): 640-643.
} 


\section{Interpreting Video Evidence in Court}

Relatedly, video evidence of police-public encounters is being used in court. Particularly, the evidence is being used to decide civil rights cases (like use of excessive force) at the summary judgment stage, rather than during a jury trial. ${ }^{204}$ However, Scott has largely changed the way that judges interpret evidence at the summary judgment stage. Before Scott, judges were to construe evidence "in the light most favorable to the non-movant," so "if the video reasonably could have been interpreted in a way that would tell a story favorable to the plaintiff's claim, the Court was obligated to adopt that understanding for summary judgment purposes." 205 After Scott, several lower court judges have been "emboldened to give more weight to the factual inferences they themselves are inclined to draw from videos," instead of largely deferring to the plaintiff's story. ${ }^{206}$

Moreover, some studies have shown that viewers tend to have an exaggerated confidence in their ability to understand visual evidence. ${ }^{207}$ The fact that judges may not be as adept at interpreting video footage as they believe may create difficulty as judges are called upon to interpret video at trial. "Legal reasoning is ... based on linear, deep analysis." 208 Attorneys and judges spend years learning to read the law -- they learn to pay attention to the way that "a particular word or subtle shift in a sentence's emphasis can influence or even alter a reader's understanding." ${ }^{209}$ However, many attorneys and judges have no training in understanding the subtleties of video evidence. Thus, they may assume that they can reasonably interpret video, when they are actually oversimplifying. In the context of granting summary judgment, "when judges evaluate a summary judgment record, they should be mindful that what might initially appear to be a weak case of pretext is not the same as no case." 210

Finally, the presence of video evidence may lead to an excessive incentive to plea bargain, given the outsized impact that footage may have in court. Pointing to the introduction of bodyworn cameras in her county, a defense attorney in Kentucky stated: "It makes it much easier for them to understand a guilty plea is probably going to be in their best interest, because you don't want a jury to see this." 211 The Chief of Topeka police similarly noted that when suspects of domestic violence cases are shown footage from body-worn cameras, they often plead guilty right away. ${ }^{212}$ There is a risk, however, that plea bargains may occur even in cases where footage is less than conclusive, due to a lack of appreciation for how ambiguous and uncertain seemingly "obvious" footage can be.

\footnotetext{
${ }^{204}$ Howard M. Wasserman, “Orwell's Vision: Video and the Future of Civil Rights Enforcement.” Md. L. Rev. 68 (2008), p. 622.

${ }^{205}$ Wasserman, “Orwell’s Vision,” p. 624.

${ }^{206}$ Ibid, p. 630.

${ }^{207}$ Elizabeth G. Porter, “Taking Images Seriously” (April 29, 2014), Columbia Law Review, Vol. 114, No. 7 (2014), 1754.

${ }^{208}$ Ibid, p. 1770.

${ }^{209}$ Ibid, p. 1696.

${ }^{210}$ Trott v. H.D. Goodall Hosp., 66 A.3d 7, 14-15 (Me. 2013).

211 "In Kentucky, Courts Are New Frontier for Police Body Cameras,” WDRB Sunday Edition, accessed January 29, 2015, http://www.wdrb.com/story/26817494/in-kentucky-courts-are-new-frontier-for-police-body-cameras.

${ }^{212}$ PERF Report, p. 10
} 


\section{Footage as a Performance Metric}

In many cases, police officers have welcomed body-worn cameras as instruments for exonerating officers against fraudulent complaints, as well as for singling out poorly performing officers. ${ }^{213}$

However, using body-worn camera footage as a performance metric could also have negative effects. Officers may hesitate to use their discretion, or to act creatively, if it means deviating from workplace protocols. ${ }^{214}$ While police officers in the Orlando Police Department study selfreported that body-worn cameras would not reduce their likelihood to respond to calls to service or impact their efficacy, ${ }^{215}$ the effects may vary across police departments based on institutional culture and other factors. An ACLU statement notes that supervisors may misuse footage of minor violations to hold against police union activists and whistleblowers, ${ }^{216}$ a concern that may require third-party oversight. ${ }^{217}$

Some department policies that we have examined suggest using video as a training tool, but are less supportive of using it as a performance metric. The police department of Burlington, Vermont explicitly affirms that a recording that demonstrates an officer making a mistake or being non-compliant should be used to increase the officer's performance, and not to enhance disciplinary actions against him. ${ }^{218}$ Likewise, San Diego's policy states: "It is NOT the intent of the Department to review digital evidence for the purpose of general performance review ... or to discover policy violations." 219 While such policies address the concern about footage being used to unnecessarily penalize officers, they simultaneously raise questions about when and how footage will be used as a mechanism of oversight. Are some policies prohibitive to the use of body-worn camera footage for accountability purposes? Would it be valuable to track police conduct in order to identify areas where policy or training improvements could reduce negative police-civilian interactions?

\section{Data on Police-Civilian Interactions}

One of the potential benefits of body-worn camera video is that it can provide qualitative and quantitative data on rates and types of confrontation that may explain disparities in use of force between individual officers. For example, a police officer may receive a higher rate of complaints because he or she more frequently patrols areas where there is a higher likelihood of confrontation.

The data gathered from body-worn cameras can also provide a better understanding of police practices on a broad scale. For example, it can be used to compare what "use of force" looks like on the ground across police departments. Researchers at the Center for Policing Equity are

\footnotetext{
${ }^{213}$ PERF Report, p. 7.

${ }^{214}$ Ethan Bernstein, "How Being Filmed Changes Employee Behavior," Harvard Business Review, September 12, 2014, accessed

January 24, 2015, https://hbr.org/2014/09/how-being-filmed-changes-employee-behavior.

215 Jennings et al, "Cops and Cameras," p. 552.

216 "Police Body-Mounted Cameras: With Right Policies in Place, a Win For All," American Civil Liberties Union, October 9, 2013, https:/www.aclu.org/technology-and-liberty/police-body-mounted-cameras-right-policies-place-win-all.

${ }^{217}$ PERF Report, p. 25.

${ }^{218}$ Burlington Police Department, "Department Directive DD14 DigitalImaging, Digital Audio \& Video, and Body Worn Camera Systems," p. 6.

${ }^{219}$ San Diego Police Department, “Axon Body Worn Cameras,” p. 9.
} 
working to build a national database on police behavior, to track practices such as police stops and use of force. ${ }^{220}$

In an effort to promote greater transparency and accountability in community policing, bodyworn camera footage could be used as an assessment tool by a third-party actor tasked with analyzing it. In some ways, this type of footage usage would directly contradict sound policy recommendations on retention and access to footage, but given that the number one goal of body-worn cameras is to promote civil rights initiatives, it is worth considering how a sudden influx in data from body-worn cameras could support that purpose. If footage is accessed for evaluative purposes, it could be the basis for national cross-comparisons in policing practices especially as they are implemented across the country around the same time frame. In particular, footage could be used to generate data and analysis of incidents where unarmed civilians have fatal encounters with police, in line with the public cries for mandatory body-worn cameras.

One of the challenges of incentivizing departments to share their footage and data is that they risk being penalized because they are "in the room," as opposed to departments that do not willingly share their data, or even their policies. Thus, researchers, advocates, and policy makers should consider how data can be collected and analyzed in the aggregate to foster the creation of improved policing policies, practices, and standards across 12,501 police departments, without penalizing the departments who agree, effectively, to be surveilled in the interest of providing greater accountability to the public. This rationale is very much in line with the policies in some departments that emphasize that footage will be used to improve department policies and training, rather than for enhanced discipline.

\footnotetext{
${ }^{220}$ Phillip Atiba Goff, “America's Lack of a Police Behavior Database Is a Disgrace. That's Why I'm Leading a Team to Build One,” The New Republic, August 25, 2014, http://www.newrepublic.com/article/119207/police-behavior-database-why-one-doesnt-exist-andwhy-one-soon-will.
} 


\section{Conclusion and Future Work}

While the implications of body-worn cameras are unknown, it is clear that these technologies will become increasingly widespread in the near future. Given the rapid pace of their adoption, supporting policies and legal frameworks surrounding their regulation will likely struggle to keep up. Moving forward, it will be crucial to maintain awareness of the key issues at stake. Public interest groups are in the position to help shape the debate. Researchers can aid that effort, as research and analysis will allow public interest groups to better understand the implementation and deployment of new policing technologies, and to ensure that the effects of body-worn cameras and other surveillance technologies are consistent with the goals outlined for their use.

Without empirical evidence, it is difficult to evaluate whether or not body-worn cameras and other technologies are advancing or infringing upon civil rights and civil liberties. As such, debates often focus on hypothetical cases, fears and anxieties, and idealized outcomes.

Recognizing the potential for both benefits and harm, we recommend that all concerned actors seek out empirical evidence to assess the following:

1) Is the civilizing effect of body-worn cameras seen in early pilot studies generalizable? What are the conditions that increase the likelihood of this outcome?

2) Do body-worn cameras increase or decrease police misconduct? What additional factors contribute to this outcome (e.g., geography, type of encounter, etc.)?

3) How conclusive is footage in providing evidence of an encounter? When, where, and under what circumstances do other forms of testimony contradict the information presented by video footage? Are certain kinds of encounters more likely to create conflicting interpretations?

4) How do body-worn cameras affect law enforcement officers' experiences on the job? Do they make policing easier, or more difficult? What are the particular challenges or benefits associated with them?

5) Do communities feel more or less safe when body-worn cameras have been implemented? Does this differ based on the vulnerable nature of certain communities (e.g., immigrants, communities of color, etc.)?

6) Does camera footage alter the pathway towards justice? Is there a perceived or quantifiable difference in plea bargains when police body-worn camera footage is used as a factor? Is there a perceived or quantifiable difference in prosecutions of officers in police-involved shootings?

7) What are the economic implications of implementing these technologies? What other services and tools are eliminated to provide funding for the purchase and support of body-worn cameras?

8) How do courts, jurors, journalists, police officers, advocates, and the public interpret video footage? Are there salient differences depending on role, geography, or demographics? 


\section{Appendix I:}

\section{Early Experiences From The Field}

What follows is an overview of current use from a wide range of police jurisdictions that have either implemented permanent body-worn camera programs or tested the cameras on a pilot basis. The university-led empirical studies (marked "Study Conducted" below) were conducted with individual police departments, using either officer self-reporting or randomized-control trials, as noted. These early analyses illustrate some of the successes, obstacles, and results of implementing a body-worn camera program. However, none of these studies are systematic, generalizable, or even comparable. When thinking about widespread deployment, these should be understood as pilot studies only.

\section{Rialto, CA (Study Conducted)}

The Rialto Police Department is credited with conducting the first experimental evaluation of the use of body-worn cameras in the U.S. ${ }^{221}$ In February 2012, Rialto outfitted half of the department's 54 patrol officers with TASER AXON body-worn cameras ${ }^{222}$ and began experimental shifts over a period of twelve months in which officers filmed all encounters. ${ }^{223}$ The study found that when officers used the cameras, there was a 50\% drop in use of force incidents, ${ }^{224}$ as well as an $88 \%$ decrease in complaints against officers. Anecdotal evidence reported that the public tended to be more polite when they knew cameras were rolling, and individuals were more likely to retract fraudulent complaints. ${ }^{225}$

\section{Mesa, AZ (Study Conducted)}

In Mesa, Arizona, officers were equipped with TASER body-worn cameras in 2012 as part of a year-long study. ${ }^{226}$ The study found that officers wearing cameras made more traffic stops and issued more tickets, but conducted significantly fewer stop-and-frisk searches. Researchers suggested that the presence of the body-worn cameras made all of the department's "officers [think] more carefully about their jobs, and what the consequences of their actions would be, whether they were being recorded or not." ${ }^{227}$ Like in Rialto, the study indicated that the cameras caused a significant decrease in the number of complaints filed against officers. The 50 officers wearing cameras were the subject of only eight complaints during the first 8 months of the study, while the 50 officers who did not wear cameras were the subject of 23 complaints during that same period. ${ }^{228}$

\footnotetext{
${ }^{221}$ Farrar and Ariel, "Self-Awareness to Being Watched and Socially-Desirable Behavior," p. 9.

222 White, Assessing the Evidence, p. 17.

${ }^{223}$ Farrar and Ariel, "Self-Awareness to Being Watched and Socially-Desirable Behavior," p. 2.

${ }^{224}$ Ibid, p. 8.

${ }^{225}$ Rory Carroll, "California Police Use of Body Cameras Cuts Violence and Complaints."

${ }^{226}$ Mesa Police Department, On-Officer Body Camera System: Program Evaluation and

Recommendations (2013), p. 2, accessed February 9, 2015, http://issuu.com/leerankin6/docs/final_axon_flex_evaluation_12-3-13-;

"Mesa Police Using Body Cameras," Live 85212/85209 City Guide, accessed January 10, 2015, http://southeastmesa.com/mesa-policeusing-body-cameras/.

${ }^{227}$ Earl Ofari Hutchinson, "Would a Body Camera Have Saved Michael Brown?"

${ }^{228}$ White, Assessing the Evidence, p. 21.
} 


\section{Phoenix, AZ (Study Conducted)}

In April 2013, the Phoenix Police Department began a year-long study using VIEVU bodyworn cameras. ${ }^{229}$ As with the Rialto and Mesa police departments, complaints against officers in Phoenix appeared to decrease following the use of body-worn cameras. "Complaints against officers wearing body cameras dropped by 23 percent during the testing period, compared to a nearly 11-percent increase in complaints for the officers without them." ${ }^{230}$ Like in Rialto, anecdotal evidence from the study found that the use of body-worn cameras had a "civilizing effect" on civilians who recognized that they were being recorded. ${ }^{231}$ While the Rialto and Mesa Police Departments had elected to store video data via Evidence.com, the Phoenix Department chose to store its data internally. ${ }^{232}$

\section{Seattle, WA}

The Seattle Police Department's experience with public records requests exemplifies how data storage and redaction of sensitive material can be major challenges for police departments. In December 2014, the Seattle Police Department launched a six-month pilot program by outfitting 12 officers with body-worn cameras. ${ }^{233}$ A citizen, who was anonymous at the time, placed a public-disclosure request (per Washington State's Public Records Act) for all written reports, patrol-car video footage, and, once available, all body-worn camera footage on a daily basis. ${ }^{234}$ The request entailed reviewing and releasing 1.6 million videos from dashboard-mounted cameras alone. ${ }^{235}$ Attempting to coordinate feasible methods for granting disclosure requests on a large scale, the Seattle Police Department hosted a "hackathon" in December 2014, to develop tools for redacting private details. Overall, the Seattle PD declared the session a success, and the individual who placed the bulk requests agreed to drop them until the Department could negotiate a schedule for releasing footage. ${ }^{236}$ The Department found that while some aspects of the process could be automated, other aspects still require human review. ${ }^{237}$

\section{Albuquerque, NM}

In 2012, the Albuquerque Police Department came under a Department of Justice investigation over its high rate of police shootings of civilians. ${ }^{238}$ In an April 2014 report to

\footnotetext{
${ }^{229}$ Ibid, p. 15.

${ }^{230}$ Megan Cassidy, "Phoenix police: Body Cameras Beneficial But Costly," Arizona Central, accessed February 9, 2015, http://www.azcentral.com/story/news/local/phoenix/2015/01/21/phoenix-police-body-cameras-beneficial-costly/22142475/. 
Albuquerque Mayor Richard J. Berry, the Department of Justice Civil Rights Division praised the Department for adopting body-worn cameras as an effort towards greater transparency. However, it noted inconsistencies in their implementation, including repeated instances of officers switching off cameras prior to incidents. The report concluded that the Department had "insufficient oversight, inadequate training and ineffective policies." ${ }^{239}$ In January 2015, two Albuquerque police officers were charged with murder after fatally shooting a homeless man. One officer's helmet camera filmed the incident. The video was released publicly and led to local calls for prosecution of the two officers. The New York Times notes that this will be one of the first instances where wearable camera footage is the primary evidence used to justify charges against an officer. ${ }^{240}$

\section{Orlando, FL (Study Conducted)}

In 2013, the University of South Florida partnered with the Orlando Police Department to equip 50 officers with TASER AXON Flex body-worn cameras for a year-long study. The study found that police officers were open and supportive of body-worn cameras and believed them to be an effective tool in reducing citizen complaints against officers. However, they did not agree that cameras would impact their own rate of use of force. ${ }^{241}$ The initially positive reception has led the department to consider agency-wide adoption, although the department has cited the high cost of data storage and lack of personnel resources as major obstacles to implementation. ${ }^{242}$

\section{Oakland, CA}

Oakland, California began using body-worn cameras in late 2010. The department currently has 619 cameras, and stores its video indefinitely. ${ }^{243}$ Between 2013 and 2014, the Oakland Police Department disciplined its officers 24 times for disabling or failing to activate their cameras. The most common punishment was a "written reprimand," or a one to three day suspension, although one officer was terminated for repeatedly failing to activate his camera. ${ }^{244}$ Despite some officers' failure to use their body-worn cameras according to department policy, the Oakland Police Department reported a significant reduction in use of force and deadly force incidents. ${ }^{245}$ Overall, the department believes that the cameras are a worthwhile investment. ${ }^{246}$

\footnotetext{
${ }^{239}$ U.S. Department of Justice, Civil Rights Division, letter to Richard J. Berry, Mayor of City of Albuquerque (April 10, 2014), accessed January 14, 2015, http://www.justice.gov/crt/about/spl/documents/apd findings 4-10-14.pdf.

${ }^{240}$ Rick Rojas and Joseph Kolb, "Albuquerque Officers Are Charged With Murder in Death of Homeless Man," The New York Times, January 12, 2015, accessed January 14, 2015, http://www.nytimes.com/2015/01/13/us/2-albuquerque-officers-face-murder-charges-indeath-of-homeless-man.html.

${ }^{241}$ Wesley G. Jennings, Lorie A. Fridell, and Mathew D. Lynch, "Cops and Cameras: Officer Perceptions of the Use of Body-Worn Cameras in Law Enforcement," Journal of Criminal Justice 42 (6), 2014: 549-56.

${ }^{242}$ Mark Schlueb, "Orlando Police Warming up to Body Cameras."

${ }^{243}$ Tim Cushing, "Oakland PD Body Cams Help Cut Police-Involved Shootings From 8 A Year To Zero In The Last 18 Months," Techdirt, accessed January 12, 2015, https:/www.techdirt.com/articles/20141218/08520629477/oakland-pd-body-cams-help-cut-policeinvolved-shootings-8-year-to-zero-last-18-months.shtml.

${ }^{244}$ Cyrus Farivar, "Oakland Cops Disciplined 24 Times for Failing to Turn on Body-Worn Cameras," Ars Technica, December 15, 2014, acccessed January 15, 2015, http://arstechnica.com/tech-policy/2014/12/oakland-cops-disciplined-24-times-for-failing-to-turn-on-bodyworn-cameras/.

${ }^{245}$ Tim Cushing, "Oakland PD Body Cams Help Cut Police-Involved Shootings From 8 A Year To Zero In The Last 18 Months."

${ }^{246}$ Ian Lovett, "In California, a Champion for Police Cameras," New York Times, August 21, 2013, accessed January 28, 2015, http://www.nytimes.com/2013/08/22/us/in-california-a-champion-for-police-cameras.html?pagewanted=all\&_r=0.
} 


\section{New Orleans, LA}

Since 2010, the New Orleans Police Department has been under investigation by an independent monitor assigned by the Department of Justice. In a 2014 quarterly report, the monitor reviewed 145 Use of Force Reports logged by the NOPD's Force Investigation Team between January and May 2014, and found documentation of footage of Use of Force incidents in only 49 cases, ${ }^{247}$ potentially indicating a failure to record. If rules regarding the activation of cameras are not enforced, then officers can neglect to record during incidents where footage can provide an account of what happened. In August 2014, for example, an NOPD officer turned off her body-worn camera just prior to fatally shooting a man during a traffic stop arrest. ${ }^{248}$

\footnotetext{
${ }^{247}$ Office of the Consent Decree Monitor, "New Orleans Consent Decree Monitor Third Quarterly Report,” (August 31, 2014), p. 24, http://media.nola.com/crime impact/other/NOPD-DECREE-0814-REPORT.pdf.

${ }^{248}$ Ken Daley, "Cameras Not on Most of the Time When NOPD Uses Force, Monitor Finds," Times-Picayune, NOLA.com, September 4, 2014, accessed January 12, 2015, http://www.nola.com/crime/index.ssf/2014/09/cameras_not_on_most_of the tim.html.
} 


\section{Works Cited}

Amazon Web Services. n.d. “AWS | US Federal Government.” Amazon Web Services, Inc, accessed February 9, 2015. http://aws.amazon.com/federal/.

American Civil Liberties Union. 2013. "You Are Being Tracked: How License Plate Readers Are Being Used to Record Americans' Movements." American Civil Liberties Union, July 2013. https://www.aclu.org/files/assets/071613-aclualprreport-opt-v05.pdf.

Baker, Thomas J. 2011. "Biometrics for Intelligence-Led Policing: The Coming Trends." The Police Chief 78 (April 2011): 38-45.

http://www.policechiefmagazine.org/magazine/index.cfm?fuseaction=display arch\&article id=2358\&issue $\mathrm{id}=42011$.

Ball, Kirstie, Kevin Haggerty, and David Lyon. 2012. Routledge Handbook of Surveillance Studies. Taylor \& Francis.

BBC News. 2014a. "Facial Recognition Tested by Police." BBC News, July 15, 2014. http://www.bbc.com/news/ukengland-leicestershire-28307938.

_. 2014b. "Privacy Fears over FBI Database." BBC News, April 15, 2014.

http://www.bbc.com/news/technology-27037009.

Bernstein, Ethan. 2014. "How Being Filmed Changes Employee Behavior." Harvard Business Review. September 12, 2014. https://hbr.org/2014/09/how-being-filmed-changes-employee-behavior.

Blitz, Marc Jonathan. 2013. "The Fourth Amendment Future of Public Surveillance: Remote Recording and Other Searches in Public Space.” American University Law Review 63, no. 1(2013): 21-86. http://digitalcommons.wcl.american.edu/cgi/viewcontent.cgi?article=1899\&context=aulr.

Brucato, Ben. 2014. "The Reason Mike Brown Can’t Get Justice Has Nothing To Do With Cameras." Ben Brucato, December 4, 2014. Accessed February 18, 2014. http://www.benbrucato.com/? $\mathrm{p}=642$.

Bureau of Justice Statistics. 2010. "Local Police Departments, 2007." U.S. Department of Justice. Report prepared by Brian A. Reaves, December 2010. http://www.bjs.gov/content/pub/pdf/lpd07.pdf.

—. 2011. "Census of State and Local Law Enforcement Agencies, 2008." U.S. Department of Justice. Report prepared by Brian A. Reaves, July 2011. http://www.bjs.gov/content/pub/pdf/csllea08.pdf.

Burlington Police Department. 2014. "Department Directive DD14 DigitalImaging, Digital Audio \& Video, and Body Worn Camera Systems," Burlington Police Department, July 22, 2014. http://www.burlingtonvt.gov/sites/default/files/police/files/DD14\%20\%20Digital\%20Imaging,\%20Digital\%20Audio\%20\%26\%20Video,\%20and\%20Body\%20Worn\%20Camera\%20Syste ms.pdf.

Carroll, Rory. 2013. "California Police Use of Body Cameras Cuts Violence and Complaints." The Guardian, November 4, 2013. http://www.theguardian.com/world/2013/nov/04/california-police-body-cameras-cuts-violence-complaintsrialto.

Cassidy, Megan. 2015. "Phoenix Police: Body Cameras Beneficial but Costly." Arizona Central, January 22, 2015. http://www.azcentral.com/story/news/local/phoenix/2015/01/21/phoenix-police-body-cameras-beneficialcostly/22142475/.

Center for Democracy and Technology. 2014. "How to Police the Police: What Rules Should Govern Police Use of Body Cameras?" Center for Democracy \& Technology, November 26, 2014. https://cdt.org/blog/how-to-police-the-policewhat-rules-should-govern-police-use-of-body-cameras.

- 2015. Letter from Center for Democracy and Technology to the President's Task Force on 21st Century Policing. January 28, 2015. https://d1ovv0c9tw0h0c.cloudfront.net/files/2015/02/CDT-Body-Camera-Letter_Blog-Format.pdf.

Chayka, Kyle. 2014. “The Facial Recognition Databases Are Coming. Why Aren't the Privacy Laws?” The Guardian, April 30, 2014. http://www.theguardian.com/commentisfree/2014/apr/30/facial-recognition-databases-privacy-laws.

CJIS Solutions. 2013. "IACP Guiding Principles on Cloud Computing in Law Enforcement", CJIS Solutions, January 31, 2013. http://www.cjissolutions.com/files/2013/09/PC_tips_IACP_Cloud_computing.pdf.

Cleaver II, Congressman Emanuel. 2015. "Congressman Cleaver and Congressman Green Secure Inclusion of Body Camera Funding in President's Budget." Congressman Emanuel Cleaver, Press Release, February 2, 2015.

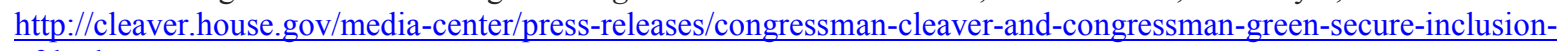
of-body.

Consent Decree Monitor, Office of the. 2014. "New Orleans Consent Decree Monitor Third Quarterly Report," Nola.com, August 31, 2014. http://media.nola.com/crime impact/other/NOPD-DECREE-0814-REPORT.pdf. 
Constitution Project Committee on Policing Reforms. 2015. "The Use of Body-Worn Cameras by Law Enforcement: Guidelines for Use and Background Paper.” The Constitution Project, January 28, 2015. http://www.constitutionproject.org/wp-content/uploads/2015/02/TCP-The-Use-of-Police-Body-Worn-Cameras.pdf.

Cooper, Cheryl. 2010. "Sending the Wrong Message: Technology, Sunshine Law, and the Public Record in Florida.” 39 Stetson Law Review 411, 413. http://www.stetson.edu/law/lawreview/media/39-2-cooper.pdf.

Cottrell, Catherine A., and Steven L. Neuberg. 2005. "Different emotional reactions to different groups: a sociofunctional threat-based approach to 'prejudice'." Journal of personality and social psychology 88, no. 5 (2005): 770.

Cushing, Tim. 2014a. "ACLU Battles Connecticut Law Enforcement Agencies Over Retention Of Licence Plate Reader Data." Techdirt, March 12, 2014. https://www.techdirt.com/articles/20140309/10300326501/aclu-battles-connecticutlaw-enforcement-agencies-over-retention-licence-plate-reader-data.shtml.

_. 2014b. "Oakland PD Body Cams Help Cut Police-Involved Shootings From 8 A Year To Zero In The Last 18 Months." Techdirt, December 23, 2014. https:/www.techdirt.com/articles/20141218/08520629477/oakland-pd-bodycams-help-cut-police-involved-shootings-8-year-to-zero-last-18-months.shtml.

Daley, Ken. 2014. "Cameras Not on Most of the Time When NOPD Uses Force, Monitor Finds." Times-Picayune, NOLA.com, September 4, 2014. http://www.nola.com/crime/index.ssf/2014/09/cameras_not_on_most_of the tim.html.

De Chant, Tim. 2013. “The Limits of Facial Recognition.” PBS NOVA Next, April 26, 2013. http://www.pbs.org/wgbh/nova/next/tech/the-limits-of-facial-recognition.

Digital Ally. n.d. "FirstVu Professional, Evidentiary, Wearable/Mountable Video System and Digital Camera.” Digital Ally, Inc. Accessed January 10, 2015. http://www.digitalallyinc.com/personal-camera.html.

Digital Media Law Project. 2014. "Recording Phone Calls and Conversations." Digital Medial Law Project, May 14, 2014. http://www.dmlp.org/legal-guide/recording-phone-calls-and-conversations.

Doland, Gwyneth. 2014. "Police Body Cameras Didn't Provide Accountability in New Mexico" Al Jazeera America, April 16, 2014. http://america.aljazeera.com/articles/2014/4/16/one-aftermathofpoliceshootingsinalbuquerquemorebodycameras.html.

Dutta, Amit Kumar, and Ragib Hasan. 2013. "How Much Does Storage Really Cost? Towards a Full Cost Accounting Model for Data Storage.” In Economics of Grids, Clouds, Systems, and Services, edited by Jörn Altmann, Kurt Vanmechelen, and Omer F. Rana, 29-43. http://secret.cis.uab.edu/media/dutta-2013-full-cost-accounting-gecon.pdf.

Electronic Frontier Foundation. n.d. “Automated License Plate Readers (ALPR).” Electronic Frontier Foundation. Accessed January 20, 2015. https://www.eff.org/foia/automated-license-plate-readers.

Evidence.com. n.d. "Security." Evidence.com. Accessed February 2, 2015. https://www.evidence.com/articles/security.

- n.d. "Evidence.com Plans.” Evidence.com. Accessed February 9, 2015. https://www.evidence.com/pricing.

Farivar, Cyrus. 2014. "Oakland Cops Disciplined 24 Times for Failing to Turn on Body-Worn Cameras.” Ars Technica, December 15, 2014. http://arstechnica.com/tech-policy/2014/12/oakland-cops-disciplined-24-times-for-failing-to-turnon-body-worn-cameras.

Farrar, Tony, and Barak Ariel. 2013. "Self-Awareness to Being Watched and Socially-Desirable Behavior: A Field Experiment on the Effect of Body-Worn Cameras on Police Use-of-Force.” Police Foundation, March 2013. http://www.policefoundation.org/content/body-worn-camera.

Federal Bureau of Investigation. n.d. "Fingerprints \& Other Biometrics.” FBI. Accessed January 23, 2015. http://www.fbi.gov/about-us/cjis/fingerprints biometrics/fingerprint biometrics.

—. 2014. “CJIS Security Policy, version 5.3 8/4/2014.” FBI, August 4, 2014. http://www.fbi.gov/about-us/cjis/cjissecurity-policy-resource-center.

Ferguson, Andrew Guthrie. 2014. "Creating Smarter Police Body-Worn Cameras." The Huffington Post, December 08, 2014. http://www.huffingtonpost.com/andrew-guthrie-ferguson/creating-smarter-police-b_b_6288482.html.

Fleeman, Michael. 2015. "L.A. Police to Get Tasers That Activate Body Cameras When Used." Reuters, January 6, 2015. http://www.reuters.com/article/2015/01/06/us-usa-california-tasers-idUSKBN0KF26B20150106.

Fort Collins, Colorado. n.d. "Facts About Body Worn Cameras (BWC)," City of Fort Collins. Accessed February 9, 2015. http://www.fcgov.com/police/pdf/facts-body-worn-camera.pdf.

Geuss, Megan. 2014. "4 Seconds of Body Cam Video Can Reveal a Biometric Fingerprint, Study Says.” Ars Technica, December 16, 2014. http://arstechnica.com/tech-policy/2014/12/4-seconds-of-body-cam-video-can-reveal-a-biometricfingerprint-study-says.

GlobeNewsWire. 2014. "VIEVU Works With Microsoft Azure Government Cloud to Enhance Public Safety Cloud Platform for Body Cameras.” GlobeNewswire, November 11, 2014. http://globenewswire.com/news- 
release/2014/11/11/681983/10107560/en/VIEVU-Works-With-Microsoft-Azure-Government-Cloud-to-EnhancePublic-Safety-Cloud-Platform-for-Body-Cameras.html.

Goff, Phillip Atiba. 2014. “America's Lack of a Police Behavior Database Is a Disgrace. That's Why I'm Leading a Team to Build One.” The New Republic, August 25, 2014. http://www.newrepublic.com/article/119207/police-behaviordatabase-why-one-doesnt-exist-and-why-one-soon-will.

Goff, Phillip Atiba, Jennifer L. Eberhardt, Melissa J. Williams, and Matthew Christian Jackson. 2008. "Not yet Human: Implicit Knowledge, Historical Dehumanization, and Contemporary Consequences." Journal of Personality and Social Psychology 94 (2): 292-306.

Grand Forks Police Department. 2014. "Directive: Body-Worn Camera Recording Equipment." Grand Forks Herald, September 9, 2014, revised November 26, 2014. http://www.grandforksherald.com/sites/default/files/4113.pdf.

Green, Marcus and Jason Riley. 2014. "In Kentucky, Courts Are New Frontier for Police Body Cameras." WDRB, October 17, 2014. http://www.wdrb.com/story/26817494/in-kentucky-courts-are-new-frontier-for-police-body-cameras.

Greenville, South Carolina Police Department. 2012. "Mobile Video/Audio Recording Equipment (MVR)." Greenville South Carolina Police Department, October 22, 2012. http://thedocumentnow.com/docnow 546891b3c6fe427ccf3b95a2.

Hermann, Peter. 2014. "D.C. Poised to Test Body Cameras for Police Officers." The Washington Post, September 6, 2014. http://www.washingtonpost.com/local/crime/dc-poised-to-test-body-cameras-for-police-officers/2014/09/06/358ebc523459-11e4-a723-fa3895a25d02 story.html.

Hern, Alex. 2014. "Hacker Fakes German Minister's Fingerprints Using Photos of Her Hands." The Guardian, December 30, 2014. http://www.theguardian.com/technology/2014/dec/30/hacker-fakes-german-ministers-fingerprints-usingphotos-of-her-hands.

Horaczek, Stan. 2014. "Body Cameras Want to Change Law Enforcement." American Photo, August 21, 2014. http://www.americanphotomag.com/node/3130.

Horowitz, David Paul. 2007. “Take My Evidence ... Please!” New York State Bar Association. October 2007.

Hudson, David. 2014. "Building Trust Between Communities and Local Police." White House Blog, December 1, 2014. http://www.whitehouse.gov/blog/2014/12/01/building-trust-between-communities-and-local-police.

Hugenberg, Kurt, and Galen V. Bodenhausen. 2003. "Facing Prejudice: Implicit Prejudice and the Perception of Facial Threat." Psychological Science 14 (6): 640-43.

Hutchinson, Earl Ofari. 2014. “Would a Body Camera Have Saved Michael Brown?” The Huffington Post, September 25, 2014. http://www.huffingtonpost.com/earl-ofari-hutchinson/would-a-body-camera-have-_b 5879356.html.

Indianapolis, City of v. Edmond, 531 U.S. 32, 37 (2000).

International Association of Chiefs of Police. 2005. The Impact of Video Evidence on Modern Policing: Research and Best Practices from the IACP Study on in-Car Cameras. Alexandria, Va.: International Association of Chiefs of Police. http://www.cops.usdoj.gov/Publications/video evidence.pdf.

. 2014. "Body-Worn Cameras Concepts and Issues Paper." IACP National Law Enforcement Policy Center, April 2014.

IACP/COPS Technology Technical Assistance Program. 2005. In-Car Cameras. Alexandria, Va.: International Association of Chiefs of Police. http://www.theiacp.org/portals/0/pdfs/InCarCamera.pdf.

Jennings, Wesley G., Lorie A. Fridell, and Mathew D. Lynch. 2014. "Cops and Cameras: Officer Perceptions of the Use of Body-Worn Cameras in Law Enforcement." Journal of Criminal Justice 42 (6): 549-56.

Kahan, Dan M., David A. Hoffman, and Donald Braman. 2009. "Whose eyes are you going to believe? Scott v. Harris and the perils of cognitive illiberalism." Harvard Law Review 122 (2009): 08-18.

Kaste, Martin. 2014. “Transparency Vs. Privacy: What To Do With Police Camera Videos?” NPR.org, December 19, 2014. http://www.npr.org/2014/12/19/371821093/transparency-vs-privacy-what-to-do-with-police-camera-videos.

Kimble, Julian. 2015. "Footage Shows St. Louis Police Officer Advising Fellow Cops to Shut Dashboard Camera Off During Arrest." Complex, February 17, 2015. http://www.complex.com/pop-culture/2015/02/footage-shows-st-louispolice-telling-officers-to-turn-dash-cam-off-during-arrest.

Laperruque, Jake. 2014. "How to Police the Police: What Rules Should Govern Police Use of Body Cameras?" Center for Democracy \& Technology, November 26, 2014. https://cdt.org/blog/how-to-police-the-police-what-rules-shouldgovern-police-use-of-body-cameras.

Las Vegas Metropolitan Police Department. 2014. “GO-009-14 Supp No 2.” August 28, 2014. https://static.spokanecity.org/documents/police/accountability/bodycamera/las-vegas-policy.pdf. 
Leadership Conference on Civil and Human Rights. 2015. Letter from Wade Henderson, President and CEO, LCCHR and Nancy Zirkin, Executive Vice President, LCCHR to the President's Task Force on 21st Century Policing, January 30, 2015. http://www.civilrights.org/advocacy/letters/2015/21st-century-policing.html.

Levy, Karen. 2014. "Beating the Box: Surveillance and Resistance in the U.S. Trucking Industry." Unpublished manuscript, Princeton University, Princeton, NJ.

Lewsey, Fred. 2014. "First Scientific Report Shows Police Body-Worn-Cameras Can Prevent Unacceptable Use-ofForce." University of Cambridge, December 23, 2014. http://www.cam.ac.uk/research/news/first-scientific-reportshows-police-body-worn-cameras-can-prevent-unacceptable-use-of-force.

Lippert, Randy, and David Murakami Wood. 2012. "New Urban Surveillance: Technology, Mobility, and Diversity in 21 st Century Cities.” Surveillance \& Society 9 (3): 257-62.

Liptak, Adam. 2013. "Supreme Court Says Police Can Take DNA Samples.” The New York Times, June 3, 2013, sec. U.S. http://www.nytimes.com/2013/06/04/us/supreme-court-says-police-can-take-dna-samples.html.

Lovett, Ian. 2013a. "In California, a Champion for Police Cameras.” The New York Times, August 21, sec. U.S. http://www.nytimes.com/2013/08/22/us/in-california-a-champion-for-police-cameras.html.

_. 2013b. "In California, a Champion for Police Cameras." The New York Times, August 21, sec. U.S. http://www.nytimes.com/2013/08/22/us/in-california-a-champion-for-police-cameras.html.

Marianna Police Department. n.d. "Mobile Video/Audio Recording Equipment," City of Marianna. Accessed January 14, 2015. http://www.cityofmarianna.com/AgendaCenter/ViewFile/Item/398?fileID=8394.

Maryland v. King, 133 S. Ct. 1958, 1968-69 (2013).

McKee, Stuart. 2014. "Microsoft Azure Government Meets Criminal Justice Information Services (CJIS) Requirements." Microsoft Azure, December 18, 2014. http://azure.microsoft.com/blog/2014/12/18/microsoft-azure-government-meetscriminal-justice-information-services-cjis-requirements/.

Miller, Lindsay, Jessica Toliver and Police Executive Research Forum (PERF). 2014. Implementing a Body-Worn Camera Program: Recommendations and Lessons Learned. Washington, DC: Office of Community Oriented Policing Services. http://www.justice.gov/iso/opa/resources/472014912134715246869.pdf.

Minneapolis Police Department. 2014. "MPD Body Camera SOP.” Minneapolis Police Department, November 5, 2014. http://www.ci.minneapolis.mn.us/www/groups/public/@mpd/documents/webcontent/wcms1p-133495.pdf.

Minnesota Government, Office of the Revisor of Statutes. 2014a. "Access to Government Data." Minnesota Government Data Practices, Section 13.03 Subdivision 1. Accessed February 9, 2015. https://www.revisor.mn.gov/statutes/?id=13.03.

- 2014b. "Criminal Investigative Data.” Section 13.82 Subdivision 7. Accessed February 9, 2015. https://www.revisor.mn.gov/statutes/?id=13.82.

Missouri Secretary of State. 2013. "Police Clerks Record Retention Schedule.” August 2013. Accessed January 15, 2015. http://www.sos.mo.gov/archives/localrecs/schedules/pdf/policeclerks.pdf.

National Association for the Advancement of Colored People. 2014. Letter from Sherrilyn Ifill, President, NAACP Legal Defense \& Education Fund, to Eric Holder August 14, 2014. http://www.naacpldf.org/files/case issue/8-142014\%20Letter $\% 20$ to $\% 20$ AG $\% 20$ Holder $\% 20$ re $\% 20$ use $\% 20$ of $\% 20$ excessive $\% 20$ force $\% 20$ by $\% 20$ police.pdf.

New Jersey, State of. "Records Retention Schedules.” State of New Jersey: Department of the Treasury. Accessed January 14, 2015. http://www.nj.gov/treasury/revenue/rms/retention.shtml.

New Orleans Police Department. 2014. "New Orleans Police Department Policy Manual, Body-Worn Camera Policy 447." Accessed January 14, 2015. http://www.fopno.com/uploads/files/Policy\%20447\%20-\%20PR447\%20\%20Body\%20Worn \%20Camera\%20EFF\%203-30-14.pdf.

New York Civil Liberties Union. 2015. "Testimony Regarding the Risks of Police Body-Worn Cameras." Written testimony of Johanna E. Miller, Advocacy Director, New York Civil Liberties Union to President's Task Force on 21st Century Policing, January 31, 2015. http://www.nyclu.org/content/testimony-regarding-risks-of-police-body-worncameras.

Newman, Lily Hay. 2014. "Seattle Police Held a Hackathon to Figure Out How to Redact Body Cam Video Streams." Slate, December 22, 2014.

http://www.slate.com/blogs/future tense/2014/12/22/seattle_police hackathon_worked_on redacting body cam vide o streams.html.

Norris, C, and G Armstrong. 1997. The Unforgiving Eye: \{CCTV\} Surveillance in Public Space. University of Hull.

Oakland Police Department. 2014. "Portable Video Management System.” Oakland Police Department, March 5, 2014. https://www.aclu.org/sites/default/files/assets/mar_14_pdrd_policy.pdf 
Payne, B. K. 2001. "Prejudice and Perception: The Role of Automatic and Controlled Processes in Misperceiving a Weapon.” Journal of Personality and Social Psychology 81 (2): 181-92.

Payton v. New York, 445 U.S. 573, 586 (1980).

Pearce, Matt. 2014. “Growing Use of Police Body Cameras Raises Privacy Concerns.” The Los Angeles Times, September 27, 2014. http://www.latimes.com/nation/la-na-body-cameras-20140927-story.html\#page=1.

Pennsylvania, General Assembly. 2013. "Regular Session 2013-2014 Senate Bill 0057 P.N. 1660." Center, PA Legislative Data Processing, December 16. http://www.legis.state.pa.us/CFDOCS/Legis/PN/Public/btCheck.cfm?txtType=HTM\&sessYr=2013\&sessInd=0\&billB ody $=$ S\&billTyp $=$ B\&billNbr $=0057 \& p n=1660$.

Peoria Police Department. 2013. "Use of Portable Recorders.” City of Peoria, July 8, 2013. https://www.peoriaaz.gov/uploadedFiles/NewPeoriaAZ/City_Departments/Police_Department/Administration/Policies Policy 450 Use_of_Portable_Recorders.pdf.

Porter, Elizabeth G. 2014. Taking Images Seriously. Columbia Law Review, Vol. 114, No. 7 (2014):1687-1782; University of Washington School of Law Research Paper No. 2014-14. Available at SSRN: http://ssrn.com/abstract=2430894.

Priester, Benjamin J. 2012. Five Answers and Three Questions after United States v. Jones (2012), the Fourth Amendment “GPS Case.” SSRN Scholarly Paper ID 2030390. Rochester, NY: Social Science Research Network. http://papers.ssrn.com/abstract=2030390.

Rankin, Lee. 2013. “On-Officer Body Camera System: Program Evaluation and Recommendations.” Mesa Police Department, December 3, 2013. http://issuu.com/leerankin6/docs/final_axon_flex_evaluation_12-3-13-.

Reveal Media. n.d. "Body Worn Video Cameras." Reveal Media. Accessed February 6, 2015. http://revealmedia.com.

Rialto Police Department. 2013. "Body Worn Video Systems.” LRIS, September 16, 2013. http://www.lris.com/wpcontent/uploads/2014/09/Rialto-Policy-on-Body-Cams.pdf.

Rojas, Rick, and Joseph Kolb. 2015. “Albuquerque Officers Are Charged With Murder in Death of Homeless Man.” The New York Times, January 12, 2015. http://www.nytimes.com/2015/01/13/us/2-albuquerque-officers-face-murdercharges-in-death-of-homeless-man.html.

RT News. 2015. “Chicago Police Start Using Facial-Recognition Software to Arrest Suspects.” RT, July $15,2013$. http://rt.com/usa/chicago-police-cctv-surveillance-135/.

San Diego Police Department. “San Diego Police Department Procedure: AXON Body Cameras.” San Diego Police Department, June 12, 2014. www.sdcitybeat.com/sandiego/file-234-.pdf.

Sanburn, Josh. 2014. "Seattle Police to Use Facial Recognition Software." Time, March 14, 2014. http://time.com/25605/seattle-police-to-use-facial-recognition-software/.

Schenwar, Maya. 2015. "The Quiet Horrors of House Arrest, Electronic Monitoring, and Other Alternative Forms of Incarceration.” Mother Jones, January 22, 2015. http://www.motherjones.com/politics/2015/01/house-arrestsurveillance-state-prisons.

Schlueb, Mark. 2014. “Orlando Police Warming up to Body Cameras.” OrlandoSentinel.com, December 12, 2014. http://www.orlandosentinel.com/news/breaking-news/os-opd-police-body-cams-20141212-story.html.

Scott v. Harris, 550 U.S. 372, 372 (2007).

Sharon, Susan. 2014. "Maine Couple Sues Portland Police after Arrest for Cell Phone Recording." MPBN News, September 16, 2014. http://news.mpbn.net/post/maine-couple-sues-portland-police-after-arrest-cell-phone-recording.

Siegel, Jacob. 2014. "Your Arrest Video Is Going Online. Who Will See It?” The Daily Beast, September 11, 2014. http://www.thedailybeast.com/articles/2014/09/11/we-re-giving-police-body-cameras-but-who-s-controlling-theirfootage.html.

South East Mesa, City of. 2015. “Mesa Police Using Body Cameras.” Live 85212/85209 City Guide. Accessed January 10, 2015. http://southeastmesa.com/mesa-police-using-body-cameras.

Stanley, Jay. 2013. "Police Body-Mounted Cameras: With Right Policies in Place, a Win For All." American Civil Liberties Union, October 9, 2013. https://www.aclu.org/technology-and-liberty/police-body-mounted-cameras-rightpolicies-place-win-all.

Stanley, Jay and Barry Steinhardt. 2002. "Drawing a Blank: The failure of facial recognition technology in Tampa, Florida." American Civil Liberties Union, January 3, 2002. http://www.epic.org/privacy/surveillance/spotlight/1105/aclu0302.pdf.

Sullivan, Jennifer. 2014a. "SPD to Test Body Cameras on a Dozen Officers." The Seattle Times, September 24, 2014, modified September 27, 2014. http://seattletimes.com/html/localnews/2024621134 bodycamerasxml.html. 
2014b. "Seattle Police-Hosted Hackathon Declared a Success." The Seattle Times, December 19, 2014. http://seattletimes.com/html/localnews/2025273007 hackathonxml.html.

Sullivan, Jennifer, and Steve Miletich. 2014. "Costly Public-Records Requests May Threaten SPD Plan for Body Cameras." The Seattle Times, November 19, 2014. http://seattletimes.com/html/localnews/2025060346 spdcamerasxml.html.

TASER International. n.d. “Taser Cam HD.” TASER International. Accessed January 12, 2015. http://www.taser.com/products/on-officer-video/taser-cam-hd.

- n.d.“About AXON Cameras from TASER International.” TASER International. Accessed Dec. 22, 2014. http://www.taser.com/images/press-room/TASERAXON-EVIDENCEcomPressKit020314.pdf.

. n.d. "Evidence.com Security." TASER International. Accessed February 1, 2015. https://taser-

international.cdn.prismic.io/taser-international\%2F58eb023c-674d-45a7-a0eedf77059aa1c1_evidence+com+security+-+us+v3.pdf.

- n.d."AXON body on-officer video.” TASER International. Accessed January 26, 2015. http://www.taser.com/products/on-officer-video/axon-body-on-officer-video.

Trott v. H.D. Goodall Hosp., 66 A.3d 7, 14-15 (Me. 2013).

United States v. Jones, 132 S. Ct. 945, 947 (2012).

U.S. Department of Justice, Civil Rights Division. 2014. Letter to Richard J. Berry, Mayor of City of Albuquerque. April 10, 2014. http://www.justice.gov/crt/about/spl/documents/apd findings 4-10-14.pdf.

U.S. Department of Justice, Office of Justice Programs National Institute of Justice. 2012. "A Primer on Body Worn Cameras for Law Enforcement.” U.S. Department of Justice, September 2012. https://www.justnet.org/pdf/00-BodyWorn-Cameras-508.pdf.

—. 2014. "Body-Worn Cameras for Criminal Justice: Market Survey Version 1.0.” U.S. Department of Justice, March 2014. https://www.justnet.org/pdf/Body-Worn-Camera-Market-Survey-508.pdf.

University of Cambridge. 2014. "First Scientific Report Shows Police Body-Worn-Cameras Can Prevent Unacceptable Use-of-Force." University of Cambridge, December 23, 2014. http://www.cam.ac.uk/research/news/first-scientificreport-shows-police-body-worn-cameras-can-prevent-unacceptable-use-of-force.

Utility. 2014. "Generation 2 Body-Worn Cameras and the Evidence EcoSystem." Utility, 2014. Accessed January 14, 2015. http://www.utility.com/perch/resources/generation-2-bodyworn-camera-white-paper.pdf.

VIEVU. n.d. "Veripatrol Cloud," VIEVU. Accessed February 9, 2015. http://www.vievu.com/vievuproducts/software/\#veripatrol-cloud.

Wasserman, Howard M. 2008. “Orwell's Vision: Video and the Future of Civil Rights Enforcement.” Florida International University Legal Studies Research Paper No. 08-04. http://ssrn.com/abstract=1219162.

Waytz, Adam, Kelly Marie Hoffman, and Sophie Trawalter. 2014. “A Superhumanization Bias in Whites' Perceptions of Blacks.” Social Psychological and Personality Science (2014): 1948550614553642.

Weiss, Murray. 2013. "High-Tech NYPD Unit Tracks Criminals Through Facebook and Instagram Photos - New York City - DNAinfo.com New York.” 2015. DNAinfo New York. Accessed February 16. http://www.dnainfo.com/newyork/20130325/new-york-city/high-tech-nypd-unit-tracks-criminals-through-facebook-instragram-photos/.

Welsh, Brandon C., and David P. Farrington. 2009. "Public Area CCTV and Crime Prevention: An Updated Systematic Review and MetaAnalysis.” Justice Quarterly 26 (4): 716-45.

White, Michael D. 2014. Police Officer Body-Worn Cameras: Assessing the Evidence. Washington, DC: Office of Community Oriented Policing Services.

https://ojpdiagnosticcenter.org/sites/default/files/spotlight/download/Police $\% 20$ Officer $\% 20$ BodyWorn\%20Cameras.pdf.

White, Tim. 2014. "Mass. Man Arrested after Recording Officer in Street.” Wpri.com, March 8, 2014. http://wpri.com/2014/03/06/massachusetts-man-arrested-after-recording-police-officer-in-street.

Wohlsifer, William R. and Tiler L. Thomas. 2013. “Certifying’ Documents Via Third-Party Software: Binding on the Court?” Florida Bar Journal 87 (8): 18.

Wolfcom USA. “Wolfcom Management Software With GPS.” Wolfcom USA. Accessed January 30, 2015. http://www.wolfcomusa.com/police_camera_management_software/police\%20camera\%20backend.html. 